Проблемы адаптации

\title{
МЕТАБОЛИЧЕСКИЙ ПРОФИЛЬ И СПЕРМОПРОДУКЦИЯ У ГОЛШТИНСКИХ БЫКОВ-ПРОИЗВОДИТЕЛЕЙ ЗАРУБЕЖНОЙ СЕЛЕКЦИИ ПРИ СОДЕРЖАНИИ В РАЗНЫХ КЛИМАТИЧЕСКИХ И ГЕОХИМИЧЕСКИХ УСЛОВИЯХ В РОССИИ И КАЗАХСТАНЕ
}

\author{
А.И. АБИЛОВ1, Н.А. КОМБАРОВА ${ }^{\otimes}$, Х.А. АМЕРХАНОВ 3 , С.А. ШЕМЕТЮК 2 , \\ А.С. ШАМШИДИН 1 , С.В. МЫМРИН ${ }^{4}$, Е.А. ПЫЖОВА \\ А.А. ГУДИЛИНА ${ }^{4}$, С.Ф. АБИЛОВА ${ }^{1}$, П.Г. КОМБАРОВ ${ }^{5}$, О.С. МИТЯШОВА ${ }^{1}$
}

В современных условиях потенциал высокопродуктивных животных, приспособленных к промышленной технологии содержания, должен использоваться наиболее эффективно и не зависеть от географического положения и агроклиматических ресурсов региона. В представляемом нами исследовании установлено, что отрицательный эффект региональных климатических и геохимических факторов можно минимизировать при соблюдении всех технологических регламентов. Полученные результаты расширяют представления об особенностях метаболизма быков-производителей в различных геоклиматических условиях умеренной циркуляционной зоны между 55.86 и $51.18{ }^{\circ}$ с.ш., что может представлять интерес для практики разведения голштинской породы в странах с аналогичными природными факторами. Мы сравнили адаптационный статус быков голштинской породы $(n=122)$ зарубежной селекции в возрасте 3-9 лет в условиях Центральной России (АО «Головной центр по воспроизводству сельскохозяйственных животныХ», Московская обл.), Среднего Урала (ОАО «Уралплемцентр», Свердловская обл.) и Северного Казахстана (РЦПЖ АО «АсылТулик», Акмолинская обл.). Был проведен биоэлементный мониторинг по содержанию Са, $\mathrm{P}, \mathrm{Mg}, \mathrm{Ca}: \mathrm{P}, \mathrm{Fe}$, хлоридов, $\mathrm{Se}, \mathrm{Cu}, \mathrm{Zn}$. Белково-липидный обмен и активность ферментов оценивали по содержанию в крови общего белка, альбуминов, глобулинов, мочевины, креатинина, билирубина общего, триглицеридов, холестерина, аланинаминотрансферазы (АЛТ), аспартатаминотрансферазы (АСТ) и щелочной фосфатазы, секрецию эндогенных гормонов - по содержанию тестостерона, эстрадиола, тироксина, кортизола. Спермопродуктивность оценивали по объему эякулята, концентрации сперматозоидов в эякуляте, числу сперматозоидов в эякуляте. Климатические и геохимические характеристики регионов: АО «ГЦВ» - умеренно-континентальный климат, дерново-подзолистые почвы, ОАО «Уралплемцентр» - резко-континентальный климат, коренные скальные породы с песчано-глинистыми и дерново-подзолистыми почвами; АО РЦПЖ «АсылТулик» расположен вблизи города Нур-Султан в Центрально-Северной части Республики Казахстан, суровый резко-континентальный климат, темно-каштановые почвы. В результате межрегионального исследования установлено, что макроэлементный баланс быков-производителей находился в пределах допустимых норм и не имел достоверных различий между регионами: содержание в крови Са - 2,34-2,53 ммоль/л, P - 1,47-2,01 ммоль/л, Са:P - 1,20-1,65, Mg - 0,790,98 ммоль/л. Обеспеченность животных железом в Московском регионе находилась в пределах нормы $(23,82 \pm 6,18$ мкмоль/л), в Северном Казахстане проходила по верхней границе нормы

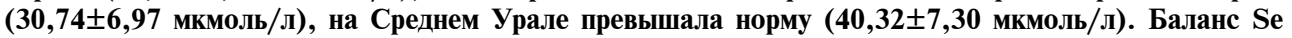
(0,72-1,13 мкмоль/л) и Си (12,6-16,0 ммоль/л) находился в допустимых пределах. На землях Москворецко-Окской провинции (АО «ГЦВ») обеспеченность производителей Zn составила 65,8 \%, в зоне сухой степи на темно-каштановых почвах (АО РЦПЖ «Асыл-Тулик») - 95,9 \% от минимального нормального значения. Повышенную в 2 раза активность ферментов в крови (по коэффициенту де Ритиса) выявили у быков в Московском регионе и в Северном Казахстане. У всех быков-производителей отмечали достаточную концентрацию как общего белка, так и его фракций. Излишнее количество белка с кормом получали производители Московского региона, о чем свидетельствует концентрация мочевины $7,57 \pm 2,82$ ммоль/л (по верхней границе нормы) и креатинина $147,45 \pm 37,94$ мкмоль/л. У производителей из Северного Казахстана отмечен синдром перегрузки железом (30,74 $\pm 6,97$ мкмоль/л) на фоне повышенного билирубина $(9,15 \pm 3,42$ мкмоль/л). Баланс стероидных гормонов свидетельствовал о легком дефиците тестостерона $(39,17 \pm 5,06$ нмоль/л) и избытке кортизола $(226,75 \pm 45,62$ нмоль/л) у быков-производителей из Московского региона по сравнению с Уралом (соответственно 50,36 $\pm 5,80$ и 138,81 $\pm 21,48$ нмоль/л) и Казахстаном $(52,79 \pm 4,14$ и 190,50 $\pm 50,30$ нмоль/л) (разница статистически не достоверна). Среднее содержание тироксина находилось в пределах физиологически допустимой нормы - от 66,65 3,52 нмоль/л на

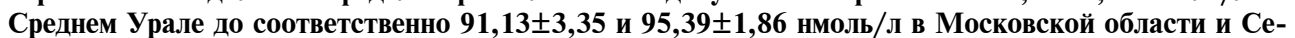
верном Казахстане. Концентрация эстрадиола в крови варьировала от 0,197 $\pm 0,02$ нмоль/л в Московском регионе до 0,234 $\pm 0,02$ и 0,276 $\pm 0,04$ нмоль/л в Северном Казахстане и на Среднем Урале, что соответствует значениям физиологической нормы (0,2-0,4 нмоль/л) для быков-производителей. Средний объем эякулята варьировал от 3,72 до 4,87 мл при средней концентрации сперматозоидов 1,21-1,52 млрд/мл и общем числе сперматозоидов в эякуляте 5,32-6,00 млрд (разница 
между показателями статистически не достоверна). Следовательно, при стабилизации условий содержания и строгом нормировании потребностей производителей в питательных и минеральных веществах, а также регуляции светового режима (утренне-дневная солнечная инсоляция, соблюдение темноты в ночное время) можно избежать отрицательного влияния климатических и геохимических факторов на племенных животных.

Ключевые слова: быки-производители, голштинская порода, сперматозоиды, метаболический баланс, белково-липидный баланс, биоэлементный баланс, эндогенные гормоны, климатические зоны, адаптация.

В современных условиях, когда производство молока сконцентрировано на крупных предприятиях, потенциал высокопродуктивных животных, приспособленных к промышленной технологии содержания, должен использоваться наиболее эффективно и не зависеть от географического положения и агроклиматических ресурсов региона $(1,2)$.

В России развитие молочного животноводства определяется и лимитируется определенным набором агроклиматических факторов (3-5). Известно, что породное районирование крупного рогатого скота основано на специфике кормовых и климатических особенностей эколого-биогеохимических провинций, с чем в значительной степени связан биоэлементный статус и функции организма $(6,7)$. Традиционно молочное скотоводство тяготеет к зонам интенсивного земледелия. Территории Российской Федерации с развитым молочным скотоводством географически расположены между 60 и 50 с.ш. и с востока ограничены Саянами. По данным Bcepocсийского НИИ племенного дела (ВНИИплем, Московская обл.) за 2018 год, 70,0 \% бонитируемого молочного поголовья РФ сосредоточено на Восточно-Европейской равнине во втором климатическом поясе. На южную часть Западно-Сибирской равнины, относящуюся к третьей климатической зоне, приходится только 20,4 \% молочного поголовья крупного рогатого скота. Потенциал этих территорий может использоваться для развития молочного скотоводства в РФ.

В молочном скотоводстве по продуктивности и приспособленности к промышленным условиям мировая популярность принадлежит голштинскому скоту (8-11), несмотря на ограниченный срок продуктивного использования (12-14). Согласно данным ВНИИплем за 2018 год, в России этот срок в среднем составляет 2,0-2,3 лактации.

Распространение голштинского скота в России началось с 1970-х годов, когда в передовых хозяйствах СССР для улучшения молочной продуктивности черно-пестрого скота стали использовать завезенных по импорту быков голштинской породы (15). С 2000-х годов активно импортировалось маточное поголовье для комплектования крупных высокотехнологичных агрохолдингов, пришедших на смену малоэффективным фермерским хозяйствам (16). Из-за укрупнения молочных производств ускорилось вытеснение районированных пород за счет прилития крови, а также импорта нетелей и спермы высокопродуктивного голштинского скота (17). В результате племенные предприятия в различных регионах Российской Федерации стали массово отказываться от содержания быков районированных пород, заменяя их на импортных голштинских производителей из стран с развитым молочным животноводством - Канады, США, Франции, Германии, Нидерландов; их доля в структуре стада быков-производителей РФ составляет $60 \%(18)$.

Однако при эксплуатации высокопродуктивного голштинского скота (в том числе быков-производителей) проявились трудности, связанные с разнообразием природно-климатических условий России и непривычной для животных кормовой базой (19). В РФ накопился значительный опыт по 
изучению процессов адаптации продуктивного маточного поголовья и быков-производителей в различных климатических условиях $(20,21)$.

При трансфере высокопродуктивных животных в условия, отличающиеся от их привычной среды обитания, при резкой смене климата и часовых поясов организм испытывает адаптационный стресс, выраженный в сдвиге метаболических процессов (22-26). При длительном разведении в условиях специфического климата Сахалина отмечено адаптивное снижение продуктивного потенциала голштинского скота (27). Есть сведения, что к гипотермии голштинский скот адаптируется быстрее, чем к гипертермии $(28,29)$. Одна из причин формирования метаболического адаптационного синдрома у высокопродуктивных голштинов - несбалансированный рацион и корма несоответствующего качества $(20,30,31)$.

Быки-производители голштинской породы, полученные от высокопродуктивных матерей (32), тоже чувствительны к изменениям условий окружающей среды, качеству кормов, технологии содержания и эксплуатации. С повышением генетического потенциала продуктивности у коров-матерей все чаще отмечают адаптационный стресс, перерастающий в метаболический синдром у их сыновей. При акклиматизации быков-производителей важно минимизировать последствия изменений часовых поясов, климатических и кормовых условий (33) во избежание затяжной адаптации и стойкого снижения качества семени как реакции на стресс (34).

Качество семени зависит от физиологического статуса самца и определяет его роль в воспроизводстве потомства, которая не ограничивается собственно оплодотворением самки. Выяснено, что характер реакции на стресс в следующем поколении определяется девятью видами микроРНК (miRNA), которые присутствуют в сперме $(35,36)$. Изменения, вызванные внешними факторами, наследуются от отцов через метилирование ДНК сперматозоидов, модификацию белков, участвующих в упаковке ДНК, а также через эпигенетические модификации, вызванные изменением состава и структуры РНК, содержащейся в сперме, следовательно, самцы, находящиеся в хроническом стрессе, производят потомство со значительно ослабленной стрессовой реакцией во взрослом возрасте (37). Качество сперматозоидов влияет как на эффективность оплодотворения самки, так и на способность эмбриона выжить на протяжении всей беременности (38). Определены индивидуальные различия в экспрессии генов у быков-производителей и связь таких различий с результативностью искусственного осеменения (39). Наличие аберрантной РНК в дефектных сперматозоидах может влиять и даже нарушить ранний эмбриогенез (40). Таким образом, оксидативный стресс сперматозоидов, нейропатия и андрогенный дефицит, индуцируемые метаболическим синдромом, - наиболее значимые механизмы реализации его нейроэндокринных и репродуктивных последствий (41).

Отклонения от физиологической нормы по белково-липидному и биоэлементному статусу отражают функциональное состояние органов и систем организма, служат ранним маркером метаболического синдрома до его клинических проявлений (42). Ранее мы подробно проанализировали белково-липидный (43) и микроэлементный (44) статус быков-производителей в связи со спермопродукцией и качеством спермы. Метаболический синдром сопровождается дисфункцией эндокринной системы, в том числе андрогенным дефицитом у самцов $(45,46)$. Подробно гормональный статус высокопродуктивных быков современной селекции нами описан в предыдущих исследованиях (47-50). Эндокринная система - важнейшее регуляторное звено, поддерживающее гомеостаз. У самцов млекопитающих содержание гормонов в периферической крови варьирует в зависимости от региона 
обитания. На этот показатель влияют много факторов, в частности продолжительность светового дня как наиболее стабильная величина для конкретной широты в одни и те же периоды года. Продолжительность светового дня определяет цикличность процессов в организме, в том числе на уровне регуляторных систем (51-55). Она изменяется в течение года, наиболее отчетливо это заметно с изменением географической широты (56). Установлена прямая зависимость содержания в крови тиреотропина, пролактина, кортизола, инсулина и обратная - соматотропина, тироксина и трийодтиронина от продолжительности светового дня (57).

Широтный фактор определяется углом падения солнечных лучей, но их распределение зависит от облачности, рельефа земной поверхности, степени прозрачности воздуха. Радиационный баланс - один из основных климатообразующих факторов. Он формирует и определяет естественный теплооборот, глубину сезонных изменений температуры воздуха и почвы, скорость испарения и ряд других важных эколого-климатических характеристик местности. Таким образом, географические точки, находящиеся на одной широте, но на разных долготах находятся в различных климатических условиях (58).

В ряде исследований приведены данные об эффектах ультрафиолетовой радиации, интенсивность которой тесно связана с широтным фактором. В частности, со смещением места проживания от экватора к полюсам снижается ультрафиолетовая радиация, в организме возникает недостаток витамина D (59). Роль этого витамина не ограничивается регуляцией фосфорно-кальциевый обмена, а со снижением его количества связывают развитие метаболического синдрома и ожирения $(60,61)$.

Постоянное воздействие климатических факторов (наряду с сезонными колебаниями количества гормонов), длительность светового дня и солнечная инсоляция могут вызвать изменение функциональных резервов эндокринной системы (62).

Нужно также учитывать, что даже в пределах природной зоны адаптивность животных одной породы, но завезенных из стран с разными природно-климатическими условиями, может быть неодинакова и зависеть от множества факторов, в том числе от химических характеристик воды и почвенного покрова (7). В работе Т.Г. Крымовой с соавт. (63) выявлена закономерность колебаний концентрации микроэлементов с зональной градацией в образцах ткани в зависимости от места проживания или рождения индивида. Содержание стронция, свинца, меди и цинка в воде, почве и растениях зонально увеличивается от гумидных (влажных) к аридным (сухим) природно-климатическим зонам. Для марганца характерна обратная закономерность: наиболее высокие концентрации наблюдаются во влажных зонах, низкие в степных сухих зонах. Увеличение концентрации свинца и меди в геохимических провинциях связаны с высокими техногенными загрязнениями. Более подробно минеральный обмен и его значение для быков-производителей ранее описан в нашей работе (44).

Таким образом, количественные и качественные показатели спермы обусловлены не только генотипом, но и особенностями метаболизма и гормонального статуса индивида. Эти особенности, в свою очередь, зависят от природно-климатических факторов, которые определяются геолокацией особи. Однако в практике животноводства эти обстоятельства, как правило, не рассматриваются в совокупности. В настоящей работе нами впервые проведено комплексное (по 33 параметрам) исследование влияния климатических и геохимических условий Центральной России, Среднего Урала и 
Северного Казахстана на ферментный статус, макро- и микроэлементный баланс, белково-липидный обмен, продукцию эндогенных гормонов и формирование адаптационного статуса племенных быков-производителей голштинской породы иностранной селекции в связи со спермопродукцией. Установлено, что отрицательный эффект региональных климатических и геохимических факторов можно минимизировать при соблюдении всех технологических регламентов. Результаты исследований расширяют представления об особенностях метаболизма быков-производителей в различных геоклиматических условиях умеренной циркуляционной зоны между 55.86 и $51.18^{\circ}$ с.ш., что может представлять интерес для практики разведения голштинской породы в странах с аналогичными природными факторами.

Цель исследований - сравнить влияние климатических и геохимических условий Центральной России, Среднего Урала и Северного Казахстана на формирование адаптационного статуса импортных быков-производителей голштинской породы.

Методика. Исследование выполнено в 2017-2018 годах на 122 голштинских племенных быках иностранного происхождения в возрасте от 3 до 9 лет: 20 гол. - АО «Головной центр по воспроизводству сельскохозяйственных животных» (АО «ГЦВ», Московская обл.), 56 гол. - ОАО «Уралплемцентр» (Свердловская обл.), 46 гол. - АО РЦПЖ «Асыл-Тулик» (Акмолинская обл., Республика Казахстан). Условия кормления и содержания животных соответствовали требованиям Национальной технологии замораживания и использования спермы племенных быков-производителей (64).

Кровь для анализа брали из яремной вены (сентябрь 2017 года) в утренние часы после взятия семени. После отделения сыворотки от форменных элементов определяли активность аланинаминотрасферазы (АЛТ), аспартатаминотрансферазы (АСТ), щелочной фосфатазы (ЩФ), концентрацию альбумина, креатинина, мочевины, общего билирубина, а также общего белка и холестерина. Макроэлементы (Ca, P, Mg, Fe) определяли в сыворотке крови на биохимическом анализаторе ChemWell 2902 («Awareness Technology, Inc.», США), микроэлементы (Cu, Zn, Se, Mn) - в цельной крови на атомно-абсорбционном спектрометре Квант-2А (OOO «КОРТЭК», Россия). Концентрацию эндогенных гормонов измеряли методом иммуноферментного анализа в 2-кратной повторности с помощью лабораторных реагентов (ЗАО «Иммунотех», Россия) для эстрадиола, тироксина ТT4, кортизола и тестостерона на приборе УНИПЛАН (АФГ-01) (ЗАО «Пикон», Россия). Содержание холестерина оценивали на автоматическом анализаторе ChemWell 2902 («Awareness Technology, Inc.», США) согласно инструкции производителя.

Спермологические показатели (объем эякулята, мл; концентрация сперматозоидов в эякуляте, млрд/мл; общее число сперматозоидов в эякуляте, млрд) изучали в соответствии с Национальной технологией замораживания и использования семени племенных быков-производителей (64) и инструкцией по организации и технологии работ с производителями разных видов животных в Племенных центрах Республики Казахстан.

Статистическую обработку осуществляли в программе Microsoft Excel. В таблицах приведены средние значения $(M)$ и ошибки средних $( \pm \mathrm{SEM})$. Статистическую достоверность различий оценивали по $t$-критерию Стьюдента (при уровнях значимости $\mathrm{p}<0,05$; $<<0,01$; $\mathrm{p}<0,001$ ) и с применением программы IBM® SPSS® Statistics (https://www.ibm.com/ruru/analytics/spss-statistics-software).

Результаты. Наблюдения, проведенные нами в течение последних 
20 лет, позволили применить к анализу полученных данных ранее сделанные предварительные выводы. В настоящей работе, выполненной в рамках ЕврАзЭС, при определении степени влияние климатических и геохимических факторов на адаптацию и метаболизм импортированных быков-производителей голштинской породы учитывали их биоэлементный, белковолипидный, ферментный и гормональный статусы. Для обследования были выбраны наиболее типичные и известные племенные предприятия, находящиеся в пределах средней широты (отклонения не более $5.67^{\circ}$ с.ш.), но удаленные друг от друга по восточной долготе, что отражается на климатических и геохимических условиях географических точек, где территориально расположены племенные предприятия (все они находятся в умеренной циркуляционной зоне) (табл. 1).

\section{1. Географо-физические и климатические характеристики изучаемых регионов}

\begin{tabular}{|c|c|c|c|c|c|}
\hline \multirow{2}{*}{$\begin{array}{l}\text { Климатическая } \\
\text { зона }\end{array}$} & \multirow[t]{2}{*}{ Регион } & \multicolumn{2}{|c|}{$\begin{array}{l}\text { Географические } \\
\text { координаты }\end{array}$} & \multirow[t]{2}{*}{ BM, M } & \multirow{2}{*}{ СКО, мм } \\
\hline & & ${ }^{\circ} \mathrm{c} . \amalg$ & ${ }^{\circ}$ в.Д. & & \\
\hline \multicolumn{6}{|c|}{ II (Восточно-Евро- Московский (АО «Головной центр по воспро- } \\
\hline III (Западно-Си- & Средний Урал (ОАО «Уралплемцентр») & 56.85 & 60.11 & 255 & 497 \\
\hline бирская равнина) & Северный Казахстан (АО РЦПЖ «Асыл-Тулик») & 51.18 & 71.44 & 358 & 308 \\
\hline \multicolumn{6}{|c|}{$\begin{array}{l}\text { П р и м е ч а н и е. ВМ - высота над уровнем моря, СКО - среднегодовое количество осадков. Данные } \\
\text { взяты из Научно-прикладного справочника «Климат России» (http://aisori-m.meteo.ru/climsprn/) и Нацио- } \\
\text { нального атласа России (https://национальныйатлас.pф/cd2/about.html). }\end{array}$} \\
\hline
\end{tabular}

Московская область расположена в поясе господства континентального климата умеренных широт, характеризуется относительно мягкой зимой с редкими оттепелями и теплым сравнительно влажным летом, относится к зоне достаточного увлажнения. В Подмосковье наблюдения последних лет показывают увеличение среднегодовой и среднесезонных температур воздуха, усиление засушливости летнего периода и потепление зимнего (65). Основной климатообразующий фактор на Среднем Урале - его географическое местоположение. Уральские горы разделяют естественные синоптические районы; здесь нарушаются зональные закономерности распределения различных метеоэлементов, особенно температуры воздуха и осадков, что служит основанием выделения этой территории в отдельный климатический регион с резкой сменой погоды. Климат близок к умереннохолодному со значительным количеством осадков. В результате ритмических особенностей климата в последние годы характерно зимнее и весеннее повышение температуры воздуха (66). Территория Северного Казахстана относится к континентальной степной Западно-Сибирской климатической области с равнинным рельефом и резко континентальным климатом с дефицитом влаги (67). Несмотря на низкий агроклиматический потенциал, характеризующийся коротким вегетационным периодом и выраженной сезонностью земледелия (68), основной специализацией региона остается растениеводство, но рассматриваются перспективы развития производства молока и мяса крупного рогатого скота (69).

Биохимический анализ показал (табл. 2), что среднестатистические значения концентраций макроэлементами в плазме крови животных на обследованных племенных предприятиях во всех регионах в основном находились в пределах референсных значений (70) и не имели достоверных различий по $\mathrm{Ca}, \mathrm{P}, \mathrm{Ca}: \mathrm{P}, \mathrm{Mg}$. В организм животного макроэлементы, в частности кальций, фосфор и магний, поступают с основным рационом, и их концентрация в крови жвачных зависит от исходного качества кормов, обеспеченности витамином D и солнечной инсоляции (71). Полученные результаты (см. табл. 2) свидетельствуют о том, что обеспеченность 
быков-производителей перечисленными макроэлементами на всех предприятиях соответствует нормативным показателям с определенной зональной вариабельностью.

2. Содержание макроэлементов в крови у голштинских быков-производителей зарубежной селекции в регионах с различными климатическими и геохимическими условиями (2017 год)

\begin{tabular}{|c|c|c|c|c|}
\hline \multirow[b]{2}{*}{ Элемент } & \multicolumn{3}{|c|}{ Регион } & \multirow[b]{2}{*}{$\begin{array}{l}\text { Референсные } \\
\text { значения }\end{array}$} \\
\hline & $\begin{array}{c}\text { Московский, } \\
\text { АО «ГЦВ» } \\
(n=20)\end{array}$ & $\mid \begin{array}{c}\text { Средний Урал, } \\
\text { ОАО «Уралплемцентр» } \\
(n=56)\end{array}$ & $\begin{array}{c}\text { Северный Казахстан, } \\
\text { АО РЦПЖ «Асыл-Тулик» } \\
(n=46)\end{array}$ & \\
\hline Са, ммоль/л & $2,43 \pm 1,17$ & $2,34 \pm 0,14$ & $2,53 \pm 0,23$ & $2,06-3,16$ \\
\hline Р, ммоль/л & $1,47 \pm 0,21$ & $2,01 \pm 0,36$ & $1,98 \pm 0,33$ & $1,13-2,91$ \\
\hline $\mathrm{Ca}: \mathrm{P}$ & $1,65 \pm 0,26$ & $1,20 \pm 0,23$ & $1,31 \pm 0,23$ & $0,82-2,39$ \\
\hline Mg, ммоль/л & $0,79 \pm 0,12$ & $0,92 \pm 0,15$ & $0,98 \pm 0,35$ & $0,75-1,34$ \\
\hline $\mathrm{Fe}$, мкмоль/л & $23,82 \pm 6,18$ & $40,32 \pm 7,30$ & $30,74 \pm 6,97$ & $12,90-37,10$ \\
\hline Хлориды, ммоль/л & $100,45 \pm 2,86$ & $97,61 \pm 4,28$ & $95,69 \pm 9,28$ & $90-108$ \\
\hline
\end{tabular}

При заготовке грубых кормов в Южном Подмосковье необходимо учитывать особенность суглинистых почв на слабокарбонатных покровных отложениях Подольско-Коломенского ополья с низким естественным плодородием и недостаточным содержанием доступного магния (менее 120 мг/кг). Для кислых и сильнокислых дерново-подзолистых почв характерно вымывание магния, который при достаточном увлажнении перемещается в нижние горизонты почвы, создавая дефицит в корневой зоне растений (72). Почвенный дефицит $\mathrm{Mg}(0,79 \pm 0,12$ ммоль/л) опосредовано влиял на обеспеченность быков-производителей по нижней границе нормы для этого элемента. На Среднем Урале основная часть сельскохозяйственных угодий $(69,9 \%)$ приходится на дерново-подзолистые почвы, сформированные на богатых кальцием и магнием породах, которые отличаются от таких же почв Центральной России повышенным содержанием перегноя, повышенной емкостью обмена катионов и всего поглощающего комплекса (73). Как видно из таблицы 2, содержание $\mathrm{Mg}$ в сыворотке крови производителей из OAO «Уралплемцентр» близко к средним нормативным показателям и составляет $0,92 \pm 0,15$ ммоль/л при значениях для фосфора и кальция соответ-

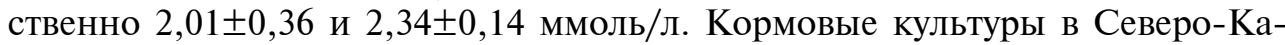
захстанской области способны аккумулировать значительные количества карбонатов Са и $\mathrm{Mg}$ из верхних пахотных горизонтов с низкой подвижностью этих соединений по почвенному профилю, так как возделываются в умеренно засушливых районах на черноземах и темно-каштановых почвах (74). Быки-производители в этом регионе хорошо обеспечены $\mathrm{Mg}$ за счет основного рациона (концентрация $\mathrm{Mg}$ и Са в сыворотке крови составила

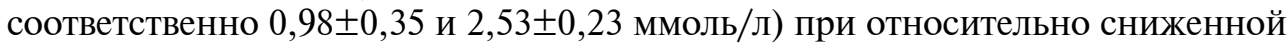
обеспеченности, в частности, фосфором (1,98 $\pm 0,33$ ммоль/л).

Несмотря на то, что концентрация доступного железа в почвенных растворах зависит от состава материнской породы и возрастает с повышением кислотности почвенного субстрата (75), быки-производители, содержащиеся во всех изучаемых регионах, не испытывали недостатка в Fe. Kонцентрация железа в крови быков в Московской области не выходила за пределы нормы, в Северном Казахстане соответствовала ее верхней границе, а на Среднем Урале превышала норматив. На техногенных территориях Урала и Северного Казахстана Fе как тяжелый металл аккумулируется в системе почва-растения-животные на темно-серых лесных, черноземах и темно-каштановых глинисто-суглинистых почвах с щелочной реакцией среды (76). При поступлении с кормами и водой большого количества железа 
в ворсинках слизистой оболочки накапливается ферритин и развивается так называемая блокада слизистой, всасывание железа прекращается (77). В сыворотке крови быков-производителей из Московского региона концентрация железа $(23,82 \pm 6,18$ мкмоль/л) не превышала нормативных границ, несмотря на загрязненность воды железом (его концентрация в некоторых источниках может достигать 10 мг/л) по сравнению с водой более глубокого залегания (78).

Таким образом, мы не выявили достоверных различий в обеспеченности быков-производителей макроэлементами, несмотря на разнообразие геохимических зон и агроклиматических условий в регионах, где расположены обследованные племенные предприятия.

Биогенные микроэлементы необходимы для формирования полноценных сперматозоидов и повышения эффективности использования быков-производителей. Микроэлементы входят в состав ферментов, витаминов, гормонов, дыхательных пигментов, структур клеток и в значительной степени влияют на качественные и количественные характеристики эякулята и фертильность сперматозоидов $(44,79-82)$. Обеспеченность животных микроэлементами (рис. 1) зависит от набора кормов основного рациона и геохимических условий местности.
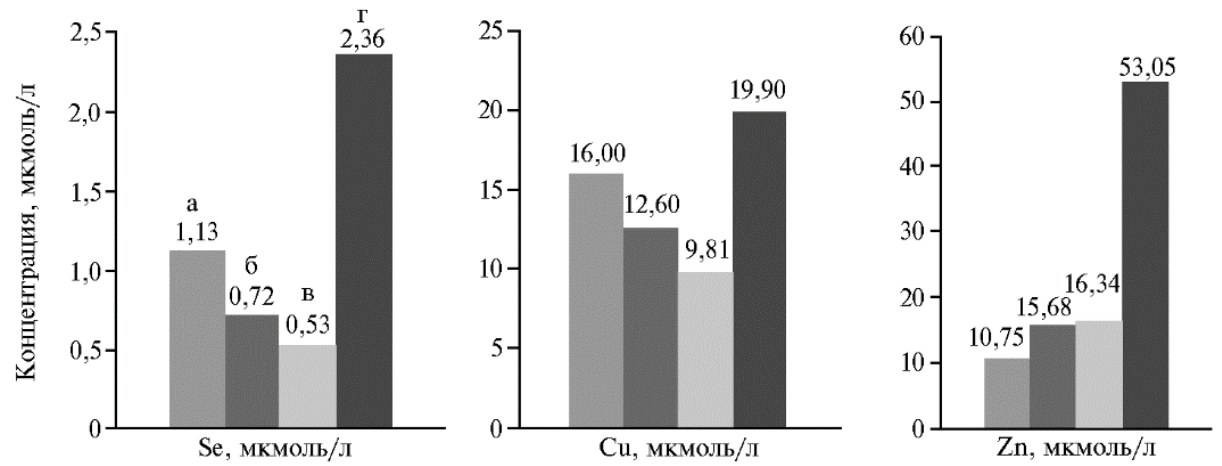

Рис. 1. Концентрация микроэлементов в крови у голштинских быков-производителей зарубежной селекции в регионах с различными климатическими и геохимическими условиями (2017 год): $\mathrm{a}-$ Московская область (АО «Головной центр по воспроизводству сельскохозяйственных животных», $n=20$ ), б - Северный Казахстан (АО РЦПЖ «Асыл-Тулик», $n=46$ ), в - нижняя граница нормы, г - верхняя граница нормы.

Изменение концентрации микроэлементов в крови у голштинских быков-производителей зарубежной селекции продемонстрировано на примере Московского региона и Северного Казахстана. По анализируемым регионам средние показатели для $\mathrm{Se}$ и $\mathrm{Cu}$ в сыворотке крови у быков-производителей находились в диапазоне референсных величин, превышая минимальную пороговую концентрацию (см. рис. 1), для $\mathrm{Zn}$ - были ниже допустимого минимума. Известно, что количество цинка в почвах увеличивается от тундровых ландшафтов к степным аридным почвам (63). Та же закономерность прослеживается по концентрации этого микроэлемента в сыворотке крови у быков-производителей. Так, в Москворецко-Окской провинции (АО «ГЦВ») на границе распространения дерново-подзолистых и серых лесных почв концентрация цинка в сыворотке крови быков составила $65,2 \%$ от порогового референсного значения, обеспечивающего нормальный обмен веществ. В зоне сухой степи на темно-каштановых почвах (Северный Казахстан, АО РЦПЖ «Асыл-Тулик») у быков-производителей содержание цинка в крови составило 95,7 \% от минимального порогового значения, что значительно выше, чем у животных в центральной части Во- 
сточно-Европейской (Русской) равнины (АО «ГЦВ»). Концентрации меди в крови быков, оставаясь в пределах референсных значений, была на $21 \%$ выше в Московской области, чем в Северном Казахстане. Показано, что для меди распределение в почвах аналогично таковому для цинка, стронция и свинца (63). Однако вследствие промышленного прессинга содержание $\mathrm{Cu}$ в почве, воде и растениях может повышаться, последствия чего мы отмечали на юге ближнего Подмосковье. Селен относится к рассеянным элементам, его содержание в почвах обусловлено главным образом материнской породой и климатическими особенностями региона. Накопление $\mathrm{Se}$ в растениях определяется его количеством и формами в почве, ее типом, кислотностью, количеством осадков и температурой окружающей среды, стадией роста самого растения (83). В настоящее время отсутствуют системные данные о содержании селена в различных типах почв (84). Концентрация селена в сыворотке крови быков на юге Подмосковья оказалась на 63,7 \% выше, чем в Северном Казахстана, хотя, согласно биогеохимическим обследованиям, почвы Московской области можно отнести к дефицитным по селену (85).

Микроэлементы в качестве кофакторов участвуют во всех жизненно важных метаболических процессах. Активность многих ферментов проявляется только в присутствии ионов металлов $\left(\mathrm{Zn}^{2+}, \mathrm{Mg}^{2+}, \mathrm{Mn}^{2+}, \mathrm{Fe}^{2+}, \mathrm{Cu}^{2+}\right.$, $\left.\mathrm{K}^{+}, \mathrm{Na}^{+}\right)(86)$.

3. Активность клеточных ферментов (IU/л, $M \pm \mathrm{SEM}$ ) в крови голштинских быковпроизводителей зарубежной селекции в регионах с различными климатическими и геохимическими условиями (2017 год)

\begin{tabular}{l|c|c|c|c}
\hline \multirow{2}{c|}{ Фермент } & \multirow{2}{*}{ Норма } & $\begin{array}{c}\text { Московский, } \\
\text { АО «ГЦВ» } \\
(n=20)\end{array}$ & $\begin{array}{c}\text { Средний Урал, } \\
\text { ОАО «Уралплемцентр» } \\
(n=56)\end{array}$ & $\begin{array}{c}\text { Северный Казахстан, } \\
\text { АО РЦПЖ «Асыл-Тулик» } \\
(n=46)\end{array}$ \\
\hline Аланинаминотрансфераза (АЛТ) & $10-36$ & $40,15 \pm 15,34$ & $68,45 \pm 16,38$ & $37,47 \pm 11,96$ \\
Аспартатаминотрансфераза (АСТ) & $41-107$ & $132,55 \pm 74,61$ & $104,00 \pm 15,95$ & $111,35 \pm 14,09$ \\
АСТ/АЛТ & $1,3-1,5$ & 3,03 & 1,51 & 2,97 \\
Щелочная фосфатаза & $31-163$ & $72,7 \pm 75,66$ & $125,25 \pm 45,43$ & $232,02 \pm 119,77$ \\
\hline
\end{tabular}

Наличие клеточных ферментов - АСТ, АЛТ и щелочной фосфатазы в крови сверх нормы служит признаком цитолиза и маркером ряда заболеваний (87-89). Как правило, повышение активности для АСТ часто совпадает со снижением для АЛТ и наоборот. АЛТ более специфична для диагностики печеночных патологий, увеличение ее активности в плазме больше свидетельствует о повреждении клеток, чем о нарушении функции печени в целом. В нашем обследовании наиболее высокий показатель по

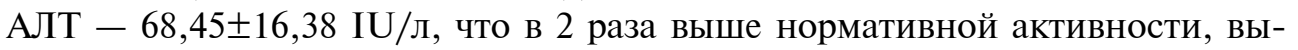
явили у быков-производителей на среднем Урале (ОАО «Уралплемцентр»), у животных из Подмосковья (АО «ГЦВ») и Северного Казахстана (АО

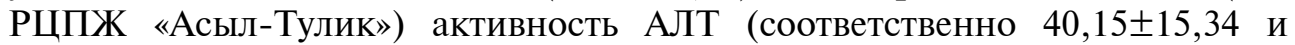
$37,47 \pm 11,96$ IU/л) находилась на верхней границе нормы (табл. 3). По АCT показатели, соответствующие верхней границе нормы, были зафиксированы у быков в ОАО «Уралплемцентре», превышение нормы - в АО РЦПЖ «АсылТулик» и АО «ГЦВ» (см. табл. 3). Величина коэффициента Де Ритиса у этих животных в 2 раза превысила нормативное значение (см. табл. 3), что свидетельствует о преобладании в метаболизме цикла трикарбоновых кислот $(90,91)$. Активность щелочной фосфатазы у быков в Северном Казахстане (АО РЦПЖ «Асыл-Тулик») на 30 \% превышала верхнюю границу референсных значений, что при нормальном кальций-фосфорном обмене служит маркером высоких функциональных нагрузок на печень и сердце и 
активной работы молодых клеток костной ткани $(92,93)$.

Повышение содержания общего и прямого билирубина, высокая активность АСТ и АЛТ могут служить диагностическим тестом заболеваний печени алиментарной этиологии (94) и характеризовать белковый обмен (81). В то же время И.А. Шкуратова с соавт. (95) считают, что к особенностям метаболического профиля быков-производителей можно отнести высокий уровень неорганического фосфора и щелочной фосфатазы. Кроме того, формирование качественных сперматозоидов, способных переносить «холодовой удар», невозможно без включения в рацион быков кормов животного происхождения, богатых белком и фосфолипидами $(96,97)$. Скудость белка в рационе производителей приводит к гормональному дисбалансу, возрастанию вторичных иммунодефицитов и снижению количественных и качественных характеристик эякулята (43).

4. Показатели белково-липидного обмена у голштинских быков-производителей зарубежной селекции в регионах с различными климатическими и геохимическими условиями ( $M \pm \mathrm{SEM}, 2017$ год)

\begin{tabular}{|c|c|c|c|c|}
\hline \multirow[b]{2}{*}{ Показатель } & \multicolumn{3}{|c|}{ Регион } & \multirow[b]{2}{*}{$\begin{array}{l}\text { Референсные } \\
\text { значения }\end{array}$} \\
\hline & \begin{tabular}{|c|} 
Московский, \\
АО «ГЦВ» \\
$(n=20)$ \\
\end{tabular} & \begin{tabular}{|c|} 
Средний Урал, \\
ОАО «Уралплемцентр» \\
$(n=56)$
\end{tabular} & \begin{tabular}{|c|} 
Северный Казахстан, \\
АО РЦПЖ «Асыл-Тулик» \\
$(n=46)$
\end{tabular} & \\
\hline Общий белок, г/л & $90,44 \pm 6,14$ & $84,83 \pm 4,05$ & $88,81 \pm 6,72$ & $70-92$ \\
\hline Альбумин (А), г/л & $32,40 \pm 2,77$ & $33,20 \pm 1,56$ & $29,22 \pm 3,40$ & $25-36$ \\
\hline Глобулин (Г), г/л & $59,08 \pm 6,13$ & $51,18 \pm 4,45$ & $59,60 \pm 7,55$ & $40-63$ \\
\hline $\mathrm{A} / \Gamma$ & 0,55 & 0,64 & 0,50 & $0,4-0,9$ \\
\hline Мочевина, ммоль/л & $7,57 \pm 2,82$ & $3,90 \pm 1,39$ & $3,40 \pm 0,65$ & $2,4-7,5$ \\
\hline Креатинин, мкмоль/л & $147,45 \pm 37,94$ & $121,04 \pm 30,90$ & $146,66 \pm 34,01$ & $62-163$ \\
\hline Билирубин, мкмоль/л & $2,26 \pm 0,51$ & $2,36 \pm 1,30$ & $9,15 \pm 3,42$ & $1,16-8,15$ \\
\hline Триглицериды, ммоль/л & $0,55 \pm 0,07$ & $0,14 \pm 0,09$ & $0,35 \pm 0,11$ & $0,09-0,37$ \\
\hline Холестерин, ммоль/л & $2,37 \pm 0,49$ & $3,46 \pm 0,61$ & $2,93 \pm 0,50$ & $2,1-8,2$ \\
\hline
\end{tabular}

У быков-производителей основные показатели белково-липидного обмена в основном находились в пределах референсных значений (табл. 4). Некоторые различия вызваны небольшими погрешностями в кормлении. Содержание общего белка и белковый фракций в крови животных было достаточным для поддержания нормального метаболизма и формирования полноценных эякулятов. Концентрация мочевины и креатинина в сыворотке крови по верхней границе нормы (соответственно 7,57 2 2,82 ммоль/л

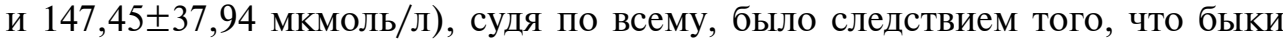
из Московского региона получали излишнее количество белка с кормом. У самцов увеличение концентрации триглицеридов обусловлено активной секрецией тестостерона (98), однако их избыток может приводить к возникновению метаболического синдрома (99). У быков-производителей из Мос-

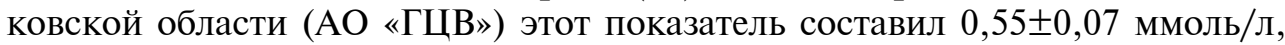
что превысило верхние границы нормы на $32 \%$. У быков из Северного Казахстана (АО «РЦПЖ» «Асыл-Тулик») высокий показатель по билирубину $(9,15 \pm 3,42$ мкмоль/л) в сочетании с повышенным содержанием железа

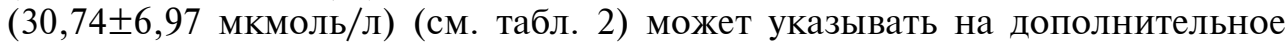
выделение гемоглобина при избыточном разрушении эритроцитов. Как следствие, может сформироваться синдром перегрузки железом (100-102), возникающий при нарушении эритропоэза, заболеваниях печени, наследственных дефектах и служащий основным фактором, предрасполагающим к накоплению железа в клетках печени.

Оптимальные показатели белково-липидного обмена были характерны для быков-производителей в Уральского регионе, что свидетельствует о сбалансированности их рациона.

Концентрация холестерина в сыворотке крови у быков-производи- 
телей во всех изучаемых регионах находилась на нижней границе референсных значений и составила 2,37-3,46 ммоль/л. Так как холестерин это предшественник стероидных гормонов (в том числе половых), его низкий уровень может быть сигналом нарушения гормонального статуса. Известно, что гормоны систем гипофиз-щитовидная железа и гипофизкора надпочечников представляют собой ключевое звено в гормональной регуляции адаптивных метаболических процессов $(102,103)$. Установлено, что в жировой ткани присутствует фермент ароматаза, под влиянием которого происходит конверсия андрогенов в эстрогены (104). Метаболические изменения, связанные с размером жировых клеток, служат пусковым механизмом снижения уровня тестостерона $(105,106)$.

В таблицах 5 и 6 представлены средние и предельные концентрации эндогенных гормонов, характеризующие репродуктивную и адаптивную функцию у быков-производителей голштинской породы, содержащихся в двух различных географических точках России и в Северном Казахстане.

5. Содержание эндогенных гормонов в сыворотке крови у голштинских быков-производителей зарубежной селекции в регионах с различными климатическими и

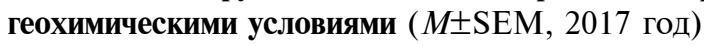

\begin{tabular}{|c|c|c|c|c|}
\hline \multirow[b]{2}{*}{ Показатель } & \multicolumn{3}{|c|}{ Регион } & \multirow[b]{2}{*}{ Среднее } \\
\hline & $\begin{array}{c}\text { Московский, } \\
\text { АО «ГЦВ» } \\
(n=19)\end{array}$ & $\begin{array}{c}\text { Средний Урал, } \\
\text { ОАО «Уралплемцентр» } \\
(n=9)\end{array}$ & $\begin{array}{c}\text { Северный Казахстан, } \\
\text { АО РЦПЖ «Асыл-Тулик» } \\
(n=17)\end{array}$ & \\
\hline Тестостерон & $39,17 \pm 5,06$ & $50,36 \pm 5,80$ & $52,79 \pm 4,14$ & $47,10 \pm 2,39$ \\
\hline Кортизол, нмоль/л & $226,75 \pm 45,62$ & $138,81 \pm 21,48$ & $190,5 \pm 50,31$ & $195,48 \pm 27,35$ \\
\hline Тироксин, нмоль/л & $91,13 \pm 3,35$ & $66,65 \pm 3,52$ & $95,39 \pm 1,86$ & $81,95 \pm 2,26$ \\
\hline Эстрадиол, нмоль/л & $0,197 \pm 0,02$ & $0,276 \pm 0,04$ & $0,234 \pm 0,02$ & $0,339 \pm 0,02$ \\
\hline
\end{tabular}

6. Вариабельность содержания эндогенных гормонов в сыворотке крови у голштинских быков-производителей зарубежной селекции в регионах с различными климатическими и геохимическими условиями (min-max, 2017 год)

\begin{tabular}{l|c|c|c|c}
\hline \multirow{2}{*}{ Показатель } & \multicolumn{3}{|c|}{ Регион } & По всей \\
\cline { 2 - 3 } & $\begin{array}{c}\text { Московский, } \\
\text { АО «ГЦВ» } \\
(n=19)\end{array}$ & $\begin{array}{c}\text { Средний Урал, } \\
\text { ОАО «Уралплемцентр» } \\
(n=9)\end{array}$ & $\begin{array}{c}\text { Северный Казахстан, } \\
\text { АО РЦПЖ «Асыл-Тулик» } \\
(n=17)\end{array}$ & $\begin{array}{c}\text { выборке } \\
(n=73)\end{array}$ \\
\hline Тестостерон, нмоль/л & $10,46-81,14$ & $28,12-79,12$ & $26,27-74,45$ & $10,46-81,14$ \\
Кортизол, нмоль/л & $21,27-728,21$ & $43,69-238,41$ & $25,60-725,32$ & $21,27-728,21$ \\
Тироксин, нмоль/л & $53,25-109,43$ & $50,20-81,20$ & $85,63-109,05$ & $32,96-126,92$ \\
Эстрадиол, нмоль/л & $0,093-0,350$ & $0,100-0,426$ & $0,073-0,374$ & $0,073-0,909$ \\
\hline
\end{tabular}

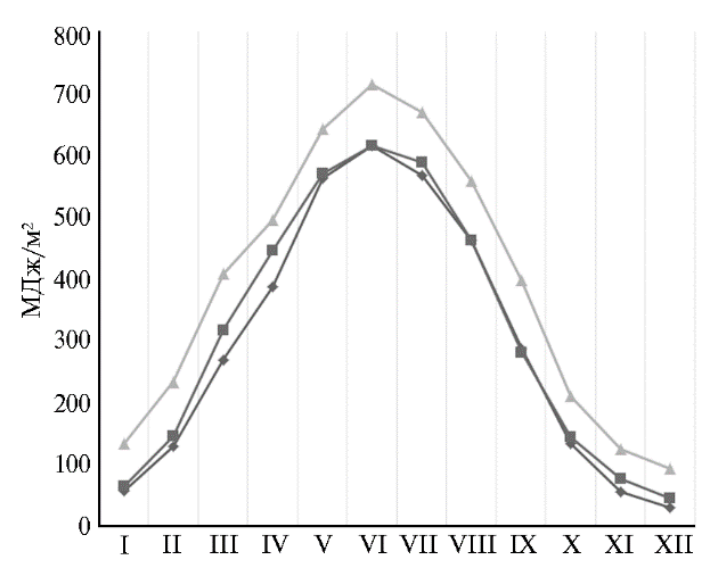

Рис. 2. Мощность суммарной (прямой и рассеянной) солнечной радиации на горизонтальной поверхности Земли по месяцам в течение года в Москве $(\diamond)$, Екатеринбурге $(\square)$ и Нурсултане $(\boldsymbol{\Delta})$ при действительных условиях облачности (http://meteo.ru/pogodai-klimat/197-nauchno-prikladnoj-spravochnik/).

Несмотря на незначительную разницу в широтности, Москва (АО «ГЦВ»), Екатеринбург (ОАО «Уралплемцентр») и Нурсултан (АО РЦПЖ «Асыл-Тулик») находятся в разных климатических зонах и различаются по среднегодовым температурам и

солнечной радиации (рис. 2), под воздействием которой в организме синтезируется до 70 \% витамина D (59), влияющего на выработку тестостерона. 
Так, в Северном Казахстане среднегодовой срез солнечной радиации превышал таковой в Южном Подмосковье на 24,0 \%, а уровень тестостерона у быков-производителей - на 25,8 \% (см. табл. 5) (107). У самцов установлено участие тестостерона на молекулярном уровне в поддержании минеральной плотности костной ткани (МПКТ) (108).

Для выработки тестостерона, как отмечалось, также характерна циркадная ритмичность (109). Самый высокий тестостероновый пик приходится на промежуток $6^{00}-8^{00}$, антипик - с $21^{00}$ до $23^{00}$. Этот физиологический цикл лежит в основе технологического режима получения спермопродукции. Годичный ритм максимального уровня тестостерона приходится на август-сентябрь с понижением в зимние месяцы и тоже связан с широтной продолжительностью светового дня и солнечной инсоляцией $(110,111)$. В наших предыдущих исследованиях (47) в крови у быков-производителей из Уральского региона в декабре был выявлен средний уровень тестостерона - 20,5 нмоль/л с вариабельностью от 4,8 до 50,6 нмоль/л по группам, причем низкие показатели (до 10 нмоль/л) зафиксировали у $50 \%$ животных в стаде. В настоящей работе (см. табл. 5) в сентябре среднее значение у быков из этого же региона составило 50,36士5,80 нмоль/л. Полученные результаты соответствуют годичной цикличности изменения концентрации тестостерона. Среди быков на изучаемых территориях минимальный средний уровень этого гормона $(39,17 \pm 5,06$ нмоль/л) отмечали у производителей из Московского региона, максимальный $(52,79 \pm 4,14$ нмоль/л) - у животных в Северном Казахстане (разница статистически недостоверна).

Для кортизола тоже характерен циркадный ритм с повышением уровня в утренние часы (112-114). В настоящей работе кровь для иссле-

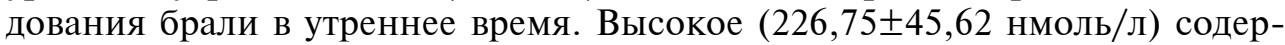
жание кортизола зарегистрировали у производителей из Московского региона, у животных в Северном Казахстане и на Среднем Урале средние значения были несколько ниже (соответственно на 16 и $39 \%$, разница статистически не достоверна) (см. табл. 5). Увеличение концентрации кортизола ассоциировано с гипертриглицеридемией, усилением белкового, жирового и углеводного обмена $(115,116)$. В стрессовых ситуациях гормон способствует быстрому высвобождению глюкозы. Избыток глюкозы в организме приводит к целому ряду метаболических осложнений: повышению осмолярности крови, увеличению продукции углекислоты и лактата, а также к жировой инфильтрации печени вследствие превращения избытка глюкозы в жирные кислоты (117). Значительная вариабельность концентрации кортизола в крови быков (см. табл. 6) показывает, что в Московском регионе и в Северном Казахстане в изученных группах есть животные, находящиеся в состоянии метаболического стресса. Ранее мы показали, что после дуплетной садки уровень кортизола у быков-производителей достоверно повышается в течение двух последующих суток, особенно у взрослых животных (47).

Эффект кортизола по усилению или ослаблению той или иной ферментативной активности дополняет тироксин, так как для проявления действия одного гормона необходимо присутствие другого (23). Среднее содержание тироксина у обследованных быков находилось в пределах физиологически допустимой нормы (51-141 нмоль/л) (см. табл. 5): на Среднем Урале - 66,65 3,52 нмоль/л, в Московской области и Северном Казах-

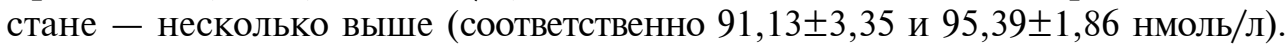
Это дает нам основание считать, что щитовидная железа у этих самцов функционирует нормально и выделяемый ею гормон (тироксин) адекватно влияет на физиологические процессы, несмотря на то что обследованные 
хозяйства находятся на территориях, дефицитных и умеренно дефицитных по йоду (118).

Для выявления достоверных различий гормонального фона между животными из различных регионов мы провели попарные сравнения показателей методом Манна-Уитни (Mann-Whitney U-test). Анализ показал высокодостоверное влияние климатических и геохимических условий (территориальный фактор) на содержание тироксина $(\mathrm{p}<0,001)$ в сыворотке крови обследованных быков-производителей в сравниваемых региональных парах предприятий: Южное Подмосковье-Средний Урал, Средний УралСеверный Казахстан (по остальным показателям не выявлено достоверных различий).

В предыдущей работе (44) мы установили, что содержание эндогенного эстрадиола в крови быков зависит от времени года $(\mathrm{p}<0,001)$. Весной средняя концентрация эстрадиола была минимальной, осенью наблюдался достоверный рост количества гормона $(\mathrm{p}<0,001)$ у $94 \%$ животных. В настоящем исследовании содержание эстрадиола варьировало (см. табл. 5) - от 0,197 $\pm 0,02$ нмоль/л в Московском регионе до 0,234 $\pm 0,02$ и 0,276 $\pm 0,04$ нмоль/л соответственно в Северном Казахстане и на Среднем Урале, что находится в пределах физиологической нормы (0,2-0,4 нмоль/л).

Результаты анализа состояния быков-производителей по характеристикам нативной спермы представлен в таблице 7 (качественные характеристики криоконсервированного семени не приведены, так как они соответствовали требованиям ГОСТ).

7. Характеристики нативной спермы голштинских быков-производителей зарубежной селекции в регионах с различными климатическими и геохимическими условиями ( $M \pm \mathrm{SEM}, 2017$ год)

\begin{tabular}{l|c|c|c}
\hline \multirow{1}{*}{ Показатель } & \multicolumn{3}{c}{ Регион } \\
\cline { 2 - 4 } & $\begin{array}{c}\text { Московский, } \\
\text { АО «ГЦВ» } \\
(n=20)\end{array}$ & $\begin{array}{c}\text { Средний Урал, } \\
\text { ОАО «Уралплемцентр» } \\
(n=56)\end{array}$ & $\begin{array}{c}\text { Северный Казахстан, } \\
\text { АО РЦПЖ «Асыл-Тулик» } \\
(n=46)\end{array}$ \\
\hline $\begin{array}{l}\text { Объем эякулята, мл } \\
\text { Концентрация сперматозоидов, }\end{array}$ & $4,87 \pm 1,8$ & $3,72 \pm 0,08$ & $4,4 \pm 0,13$ \\
$\begin{array}{l}\text { млрд/мл } \\
\text { Число сперматозоидов }\end{array}$ & $1,21 \pm 0,20$ & $1,52 \pm 0,02$ & $1,29 \pm 0,01$ \\
в эякуляте, млрд & $6,00 \pm 0,64$ & $5,60 \pm 0,16$ & $5,32 \pm 0,27$ \\
\hline
\end{tabular}

Разница между показателями, приведенными в таблице 7, статистически не значима.

Таким образом, отсутствие достоверной разницы по основным показателям, характеризующим метаболизм, между животными из различных регионов, получавшими сбалансированный рацион с учетом геохимических условий местности при сходном режиме эксплуатации согласно регламентам, предусмотренных технологией содержания и использования, свидетельствует о минимизации влияния климатических и геохимических факторов и достаточной адаптационной способности быков-производителей голштинской породы в условиях умеренной циркуляционной зоны между $55.86^{\circ}$ и $51.18^{\circ}$ с.ш. Об этом свидетельствует проведенное нами впервые комплексное сравнение состояния белково-липидного, макро- и микроэлементного, ферментативного и гормонального статуса с учетом воспроизводительной способности у быков-производителей голштинской породы, содержащихся в различных геоклиматических условиях.

Полученные нами результаты дают основания заключить, что белково-липидный и макроэлементный обмен у производителей в условиях типовой технологии кормления и содержания не имеет достоверных гео- 
графических различий и в большей части зависит от качества основных кормов рациона.

Дефицит эссенциальных микроэлементов, в частности $\mathrm{Zn}$, характерен для большей части территории России. В организме млекопитающих он поступает только с пищей. Средняя суточная потребность для половозрелого быка-производителя составляет 300-600 мг в зависимости от массы тела (нормы и рационы). В период интенсивной половой нагрузки у производителей значительно усиливается метаболизм, следовательно, растет потребление и содержание цинка в организме $(20,44)$. Цинк преимущественно секретируется предстательной железой, в существенном количестве содержится в созревающих сперматозоидах, его концентрация коррелирует с потреблением кислорода и стабильностью ядерного хроматина $(119,120)$. Содержание цинка в мужской половой системе значительно превышает таковую в других органах и тканях, его недостаток может вызывать нарушения сперматогенеза (121). Несмотря на то, что железо незаменимо в процессах кроветворения, дыхания, клеточного обмена, его избыток может инициировать перекисное окисление липидов (ПОЛ), токсическое повреждение белков и нуклеиновых кислот (122), что негативно отражается на качестве нативной спермы (123). Для определения потребности быков-производителей в эссенциальных элементах следует проводить их мониторинг в сыворотке крови, учитывая дефицит или избыток поступления в организм по результатам химического анализа воды, почв и основных кормов, компенсировать адресными премиксами. Для обеспечения животных водой в регионах с повышенным уровнем почвенного железа необходимо использовать скважины глубокого залегания и станции обезжелезивания воды.

Выявленные особенности необходимо учитывать при содержании и использовании племенных производителей в различных геохимических провинциях России, Казахстана других стран, входящих в ЕврАзЭС. Состав рационов необходимо разрабатывать с учетом не только геохимических и климатических условий места содержания, но и возможных дефицитов внутриутробного развития и постнатального доращивания быковпроизводителей.

Учитывая современные исследования нейроэндокринной регуляции полового развития самцов $(124,125)$, в условиях широкомасштабной селекции на высокую продуктивность с индексной оценкой предков необходимо уделять внимание пренатальному и раннему постнатальному развитию, определяющему будущее репродуктивное здоровье животного. Бык, имеющий высокий геномный прогноз, но сперму, не пригодную для криоконсервации (126), не имеет племенной ценности.

Проведенные нами сравнительные исследования показали, что гормоны гипоталамо-гипофизарно-гонадной и тиреоидной оси эндокринной регуляции у быков-производителей, содержащихся на средней широте в различных климатических и геохимических условиях, служат ключевым фактором долговременной адаптации к внешним условиям (23).

По нашему мнению, одна из причин снижения тестостеронового статуса у быков-производителей из Московского региона по сравнению с животными на Среднем Урале и в Северном Казахстана - солнечная инсоляция (см. рис. 2). Дефицит солнечной инсоляции и синтеза витамина D, с одной стороны, и неизбежное влияние технологических эффектов - c другой, приводят к формированию и нарастанию метаболического стресса (59, 127). Дежурное ночное освещение в животноводческих помещениях нарушает циркадные ритмы. Показано, что синяя составляющая спектра, в 
том числе искусственного освещения, в значительной степени подавляет продукцию гормона мелатонина, от секреции которого зависит качество сна животных (128). В свою очередь, мелатонин опосредовано оказывает регулирующее влияние на функции тестикул $(129,130)$. Его избыток, равно как и недостаток, приводит к дисбалансу в секреции стероидных гормонов, которая подчиняется не только циркадным, но и инфрадиадным ритмам (130). Доказана сложная взаимосвязь между сбоем циркадных ритмов и метаболизмом, изменение цикла сон-бодрствование может привести к формированию метаболического синдрома и сердечно-сосудистым заболеваниям (131). При половой активности у самцов одновременно повышается уровень тестостерона и кортизола, что предположительно связано с соперничеством, защитой территории, а также с поведением ухаживания и спаривания (132).

Мы не отметили достоверного влияния различных климатических и геохимических условий регионов на основные показатели спермопродукции у быков-производителей. Однако постоянное воздействие таких факторов в сочетании с сезонными колебаниями количества гормонов, влиянием длительности светового дня и солнечной инсоляцией может повлиять на функциональные резервы эндокринной системы $(133,134)$. В этом случае гормональный профиль быков-производителей может служить маркером пластичности организма.

Итак, при стабилизации условий содержания и строгом нормировании потребностей быков-производителей в питательных и минеральных веществах, а также регуляции светового режима (утренне-дневная солнечная инсоляция, соблюдение темноты в ночное время), можно минимизировать отрицательное влияние климатических и геохимических факторов на организм племенных животных. Полученные данные по общему числу сперматозоидов в эякуляте свидетельствуют об адаптивности голштинских быковпроизводителей в различных климатических условиях при применяемых технологиях.

\footnotetext{
1 ФГБНУ Федеральный исследовательский иентр животноводства - ВИЖ им. академика Л.К. Эрнста, 142132 Россия, Московская обл., г.о. Подольск, пос. Дубровицы, 60, e-mail: ahmed.abilov@mail.ru,270180@mail.ru,652202@mail.ru, info@vij.ru, mityashova_o@mail.ru;

2 АО «Гловной центр по воспроизводству

сельскохозяйственных животных»,

142143 Россия, Московская обл., г.о. Подольск,

пос. Быково, ул. Центральная, 3,

e-mail: komnina@list.ru $\bowtie$, csio-secr@yandex.ru;

ЗФГБОУ ВПО Российский государственный

аграрный университет-МСХА им. К.А. Тимирязева,

127550 Россия, г. Москва, ул. Тимирязевская, 49,

e-mail: h.amerhanov@rgau-msha.ru;

${ }^{4} \mathrm{OAO}$ «Уралплемиентр»,

620061 Россия, Свердловска обл., г. Екатеринбург,

ул. Сибирский Тракт, 21-й километр,

e-mail: mymrinsv@yandex.ru, gudilina.vet@mail.ru;

5 ФГБОУ ВО Московский государственный университет

им. М.В. Ломоносова, Географический факультет,

119991 Россия, г. Москва, ГСП-1, Ленинские горы,

e-mail: Lena.pyzhova@gmail.com, pavel.kombarov@mail.ru
}

Поступила в редакцию 24 сентября 2020 года HOLSTEIN BULL SIRES UNDER DIFFERENT CLIMATIC 


\title{
AND GEOCHEMICAL CONDITIONS OF RUSSIA AND KAZAKHSTAN
}

\author{
A.I. Abilov', N.A. Kombarova ${ }^{\bowtie}$, Kh.A. Amerkhanov³, S.A. Shemetyuk ${ }^{2}$, A.S. Shamshidin 1 , \\ S.V. Mymrin ${ }^{4}$, E.A. Pyzhova ${ }^{5}$, N.V. Bogolyuboval, A.A. Gudilina ${ }^{4}$, S.F. Abiloval, \\ P.G. Kombarov 5 , O.S. Mityashova1
}

IErnst Federal Science Center for Animal Husbandry, 60, pos. Dubrovitsy, Podolsk District, Moscow Province, 142132 Russia, e-mail ahmed.abilov@mail.ru, 270180@mail.ru, 652202@mail.ru, info@vij.ru, mityashova_o@mail.ru;

${ }^{2}$ Head Center for Reproduction of Farm Animals AO, 3, ul. Tsentralnaya, pos. Bykovo, Podolsk Region, Moscow Province, 142143 Russia, e-mail komnina@list.ru ( $₫$ corresponding author), csio-secr@yandex.ru;

${ }^{3}$ Timiryazev Russian State Agrarian University-Moscow Agrarian Academy, 49, ul. Timiryazevskaya, Moscow, 127550 Russia, e-mail h.amerhanov@rgau-msha.ru;

${ }^{4}$ Uralplemcentr $O A O, 21$ km, Siberian tract, Ekaterinburg, 620913 Russia, e-mail mymrinsv@yandex.ru, gudilina.vet@mail.ru;

${ }^{5}$ Lomonosov Moscow State University, Faculty of Geography, 1, Leninskie gory, Moscow, 119991 Russia, e-mail Lena.pyzhova@gmail.com, pavel.kombarov@mail.ru ORCID:

Abilov A.I. orcid.org/0000-0001-6236-8634 Kombarova N.A. orcid.org/0000-0003-3861-4465

Amerkhanov Kh.A. orcid.org/0000-0001-7680-3748

Shemetyuk S.A. orcid.org/0000-0002-1280-102X

Shamshidin A.S. orcid.org/0000-0001-5457-1720

Mymrin S.V. orcid.org/0000-0001-5173-984X

The authors declare no conflict of interests

Received September 24, 2020

Pyzhova E.A. orcid.org/0000-0001-5719-3075

Bogolyubova N.V. orcid.org/0000-0002-0520-7022

Gudilina A.A. orcid.org/0000-0002-7962-5315

Abilova S.F. orcid.org/0000-0002-3340-1631

Kombarov P.G. orcid.org/0000-0001-6713-1855

Mityashova O.S. orcid.org/0000-0002-0401-5088

doi: 10.15389/agrobiology.2021.4.730eng

\section{Abstract}

Currently, the potential of highly productive animals adapted to industrial farming should be used most effectively and not depend on the geographical location and agro-climatic resources of the region. Our study showed that the observation of required technologies minimizes effects of regional climatic and geochemical factors. Our findings give more understanding on the metabolic peculiarities of the sire bulls in various geo-climatic conditions of the $55.86^{\circ} \mathrm{N}$ and $51.18^{\circ} \mathrm{N}$ zone. This may be of interest for the practice of breeding the Holstein breed in countries with similar geo-climatic factors. We compared the influence of climatic and geochemical conditions of the Central Russia (the Head Center for the Reproduction of Farm Animals, Moscow Province), the Middle Urals (JSC Uralplemcenter, Sverdlovsk Province), and the Northern Kazakhstan (RCPZh JSC Asyl-Tulik, Akmola region) on the adaptive status of the imported Holstein 3-9-year-old bull sires $(n=122)$. Blood levels of bioelements $\mathrm{Ca}, \mathrm{P}, \mathrm{Mg}, \mathrm{Ca}: \mathrm{P}, \mathrm{Fe}$, chlorides, $\mathrm{Se}, \mathrm{Cu}$, and $\mathrm{Zn}$ were recorded. To assess protein-lipid metabolism parameters and blood enzyme activity, the total protein, albumin, globulins, urea, creatinine, total bilirubin, urea, triglycerides, cholesterol, alanine aminotransferase, aspartate aminotransferase and alkaline phosphatase were measured. The endogenous hormone levels (testosterone, estradiol, thyroxine, and cortisol) were measured. The volume of ejaculate, the concentration of spermatozoa in the ejaculate, and the number of spermatozoa in the ejaculate were assessed to evaluate sperm productivity. Climatic and geochemical characteristics of the regions were a temperate climate with sodpodzolic soils for the Moscow region, a sharply continental climate with bedrock rocks with sandyclayey and sod-podzolic soils for the Middle Urals, and sever sharply continental climate with dark chestnut soil for the Northern Kazakhstan. The study revealed that the balance of macroelements was within the permissible limits and did not have significant differences between regions, i.e., 2.34$2.53 \mathrm{mmol} / \mathrm{l} \mathrm{Ca}, 1.47-2.01 \mathrm{mmol} / \mathrm{l} \mathrm{P}$ (Ca:P 1.20-1.65), and 0.79-0.98 mmol/l Mg. The iron supply in the Moscow region was within the normal range $(23.82 \pm 6.18 \mu \mathrm{mol} / \mathrm{l})$, reached the upper limits in the Northern Kazakhstan $(30.74 \pm 6.97 \mu \mathrm{mol} / \mathrm{l})$ and exceeded the physiological level $(40.32 \pm 7.30 \mu \mathrm{mol} / \mathrm{l})$ in the Middle Urals. The balance of Se $(0.72-1.13 \mu \mathrm{mol} / \mathrm{l})$ and $\mathrm{Cu}(12.6-16.0 \mu \mathrm{mol} / \mathrm{l})$ was within allowed limits. On the soils of the Moskvoretsko-Oka geochemical province (the Head Center for the Reproduction of Farm Animals), the bulls were $65.8 \%$ provided with $\mathrm{Zn}$ compared to $95.9 \%$ provision (of that minimum allowed) observed in the dry steppe zone on dark chestnut soils of the Northern Kazakhstan. The enzymatic activity (as per the de Ritis coefficient) increased 2-fold in bulls of the Moscow region and the Northern Kazakhstan. All the sires had a sufficient concentration of both total protein and its fractions. The sires of the Moscow region fed an excessive amount of protein, as evidenced by the urea concentration at the upper limit $(7.57 \pm 2.82 \mathrm{mmol} / \mathrm{l})$ and creatinine $147.45 \pm 37.94 \mu \mathrm{mol} / \mathrm{l})$. The bulls of the Northern Kazakhstan showed iron overload syndrome of $30.74 \pm 6.97 \mu \mathrm{mol} / 1$ with an increased bilirubin of $9.15 \pm 3.42 \mu \mathrm{mol} / \mathrm{l}$. The balance of blood steroid hormones indicates a slight testosterone deficiency $(39.17 \pm 5.06 \mathrm{nmol} / \mathrm{l})$ and an excess of cortisol $(226.75 \pm 45.62 \mathrm{nmol} / \mathrm{l})$ in bulls of the Moscow region compared to the Middle Urals (50.36 \pm 5.80 and $138.81 \pm 21.48 \mathrm{nmol} / \mathrm{l}$ ) and Kazakhstan $(52.79 \pm 4.14$ and $190.50 \pm 50.30 \mathrm{nmol} / \mathrm{l})$; the differences are not statistically significant. The average level of blood thyroxine was within the physiologically permissible values, from $66.65 \pm 3.52 \mathrm{nmol} / 1 \mathrm{in}$ the Middle Urals to $91.13 \pm 3.35$ and $95.39 \pm 1.86 \mathrm{nmol} / \mathrm{l}$ in the Moscow region and the Northern Kazakhstan, respectively. The level of estradiol varied from $0.197 \pm 0.02 \mathrm{nmol} / 1$ in the Moscow region 
to $0.234 \pm 0.02$ and $0.276 \pm 0.04 \mathrm{nmol} / 1$ in the Northern Kazakhstan and the Middle Urals, which fit into physiological norms of $0.2-0.4 \mathrm{nmol} / 1$ for bull sires. The average ejaculate volume varied from 3.72 to $4.87 \mathrm{ml}$, with an average sperm concentration of $1.21-1.52 \mathrm{billion} / \mathrm{ml}$. The total number of spermatozoa in the ejaculate was 5.32-6.00 billion; the differences were not statistically significant. Therefore, stable keeping conditions, strict control of the requirements in nutrients and mineral elements, and proper light regime (morning-day solar insolation, darkness at night) make it possible to avoid the negative influence of climatic and geochemical factors on breeding animals.

Keywords: bulls, Holstein breed, spermatozoa, metabolic balance, protein-lipid balance, bioelement balance, endogenous hormones, climatic zones, adaptation.

\section{REFERENCES}

1. Surovtsev V., Nikulina Yu., Payurova E. APK: ekonomika, upravlenie,_2019, 12: 38-50 (in Russ.).

2. Foksha V., Konstandoglo A. Dairy productivity of Holstein cows and realization of their genetic potential. Bulgarian Journal of Agricultural Science, 2019, 25(Suppl 1): 31-36.

3. Shuvarin M.V., Borisova E.E., Ganin D.V., Sukhanova T.V., Shuvarina N.A., Lekhanov I.A. ANI: ekonomika i upravlenie, 2020, 2(31): 389-393 (in Russ.).

4. Kirkorova L.A., Burova I.A., Bortnevskaya E.R. Izvestiya SPbGAU, 2014, 36: 173-176 (in Russ.).

5. Shagdurova E.A. Vestnik KrasGAU, 2011, 4: 22-26 (in Russ.).

6. Yang Z., Yu T., Hou Q., Xia X., Feng H., Huang C., Wang L., Lv Y., Zhang M. Geochemical evaluation of land quality in China and its applications. Journal of Geochemical Exploration, 2014, 139: 122-135 (doi: 10.1016/j.gexplo.2013.07.014).

7. Kovalsky V.V. Geochemical ecology and problems of health. Philos. Trans. $R$ Soc. Lond. B Biol. Sci., 1979, 288(1026): 185-191.

8. Aliloo H., Pryce J.E., González-Recio O., Cocks B.G., Goddard M.E., Hayes B.J. Including no additive genetic effects in mating programs to maximize dairy farm profitability. Journal of Dairy Science, 2017, 100: 1203-1222 (doi: 10.3168/jds.2016-11261).

9. Clasen J.B., Norberg E., Madsen P., Pedersen J., Kargo, M. Estimation of genetic parameters and heterosis for longevity in crossbred Danish dairy cattle. Journal of Dairy Science, 2017, 100: 6337-6342 (doi: 10.3168/jds.2017-12627).

10. Saksa E.I., Plemyashov K.V., Anipchenko P.S. WPSIII-8 The effectiveness of the using bulls evaluated by different methods. Journal of Animal Science, 2018, 96(S3): 521-522 (doi: 10.1093/jas/sky404.1141)

11. Thompson J. Worldwide Holstein breeding. International Bull Evaluation Service, 1998, Bulletin. 19. Available: https://www.researchgate.net/publication/240610493_World_Wide_Holstein_Breeding. Accessed: 14.05.2021.

12. Milostiviy R.V., Vysokos M.P., Kalinichenko O.O., Vasilenko T.O., Milostiva D.F. Productive longevity of European Holstein cows in conditions of industrial technology. Ukrainian Journal of Ecology, 2017, 7(3): 169-179 (doi: 10.15421/2017_66).

13. Rodina N.D., Stepanov D.V. Vestnik agrarnoi nauki, 2011, 33(6): 59-62 (in Russ.).

14. Ward A., Abuargob O.M., Hdud I.M., Ruban S.Y. The influence of the genotype on the longevity and the lifelong productivity of Holstein breed. International Journal of Advance Research, Ideas and Innovations in Technology, 2018, 4(2): 2764-2768.

15. Abramova N.I., Vlasova G.S., Burgomistrova O.N., Khromova O.L., Bogoradova L.N., Zenkova N.V. Molochnokhozyaistvennyi vestnik, 2017, 3(27): 8-15 (doi: 10.24411/2225-4269-2017-00021) (in Russ.).

16. Barsukova S.Yu. Agrarnaya politika Rossii. Obshchestvennye nauki i sovremennost', 2017, 5: 3145 (in Russ.).

17. Firsova E.V., Kartashova A.P. Genetika i razvedenie zhivotnykh, 2019, 1: 62-69 (in Russ.).

18. Eskin G.V., Turbina I.S. Agrarnaya nauka, 2018, 9: 8-11 (in Russ.).

19. Alagirova Zh.T. Sel'skokhozyaistvennyi zhurnal, 2015, 8: 8-12 (in Russ.).

20. Abilov A.I., Plemyashov K.V., Kombarova N.A., Pyzhova E.A., Reshetnikova N.M. Nekotorye aspekty vosproizvodstva krupnogo rogatogo skota /Pod redaktsiei A.I. Abilova [Some aspects of cattle reproduction. A.I. Abilov (ed.)]. St. Petersburg, 2019 (in Russ.).

21. Ulimbashev M.B., Alagirova Zh.T. Adaptive ability of Holstein cattle introduced into new habital conditions. Sel'skokhozyaistvennaya biologiya [Agricultural Biology], 2016, 51(2): 247-254 (doi: 10.15389/agrobiology.2016.2.247eng).

22. Shevkhuzhev A.F., Tumov A.A. Molochnoe i myasnoe skotovodstvo, 2018, 1: 31-35 (in Russ.).

23. Kubasov R.V. Vestnik Rossiiskoi akademii meditsinskikh nauk, 2014, 69(9-10): 102-109 (doi: 10.15690/vramn.v69i9-10.1138) (in Russ.).

24. Prastowo S., Nugroho T., Mahfudhoh N., Putra F., Subiakti Y., Ratriyanto A., Susilowati A., Sutarno, Widyas N. Milk production of imported Holstein cows over different environment. IOP Conf. Ser.: Mater. Sci. Eng., 2019, 633: 012021.

25. Pangestu M., Subagyo Y., Yuwono P., Rustomo B. Heat tolerance and productivity of local and imported Holstein-Friesian cows in Indonesia. Asian-Australasian Journal of Animal Sciences, 2000, 
13(Suppl.): 505-508.

26. Marai I.F., Habeeb A.A., Farghaly H.M. Productive, physiological and biochemical changes in imported and locally born Friesian and Holstein lactating cows under hot summer conditions of Egypt. Tropical Animal Health and Production, 1999, 31(4): 233-243 (doi: 10.1023/A:1005219227668).

27. Kuznetsov V.M. Sibirskii vestnik sel'skokhozyaistvennoi nauki, 2014, 3: 85-89 (in Russ.).

28. Sharafutdinova E.B., Zhukov A. P., Rostova N.YU. Izvestiya Orenburgskogo gosudarstvennogo agrarnogo universiteta, 2016, 2(58): 156-159 (in Russ.).

29. Naranjo-Gómez J.S., Uribe-García H.F., Herrera-Sánchez M.P., Lozano-Villegas K.J., RodríguezHernández R., Rondón-Barragán I.S. Heat stress on cattle embryo: gene regulation and adaptation. Heliyon, 2021, 7(3): e06570 (doi: 10.1016/j.heliyon.2021.e06570).

30. Silvestre F.T., Carvalho T.S.M., Francisco N., Santos J.E.P., Staples C.R., Jenkins T.C., Thatcher WW. Effects of differential supplementation of fatty acids during the peripartum and breeding periods of Holstein cows: I. Uterine and metabolic responses, reproduction, and lactation. J. Dairy Sci., 2011, 94: 189-204 (doi: 10.3168/jds.2010-3370).

31. Bobe G., Young J. W., Beitz D. C. Pathology, etiology, prevention, and treatment of fatty liver in dairy cows. J. Dairy Sci., 2004, 87: 3105-3124 (doi: 10.3168/jds.S0022-0302(04)73446-3).

32. Chagas L.M., Bass J.J., Blache D., Burke C.R., Kay J.K., Lindsay D.R., Lucy M.C., Martin G.B., Meier S., Rhodes F.M., Roche J.R., Thatcher W.W., Webb R. New perspectives on the roles of nutrition and metabolic priorities in the subfertility of high-producing dairy cows. J. Dairy Sci., 2007, 90: 4022-4032 (doi: 10.3168/jds.2006-852).

33. Mathevon M., Buhr M.M., Dekkers J.C. Environmental, management, and genetic factors affecting semen production in Holstein bulls. J. Dairy Sci., 1998, 81(12): 3321-3330 (doi: 10.3168/jds.S0022-0302(98)75898-9).

34. Anbaza Yu.V. Vestnik Krasnoyarskogo gosudarstvennogo agrarnogo universiteta, 2017, 10: 174-180 (in Russ.).

35. Rodgers A.B., Morgan C.P., Bronson S.L., Revello S., Bale T.L. Paternal stress exposure alters sperm microRNA content and reprograms offspring HPA stress axis regulation. J. Neurosci., 2013, 33(21): 9003-9012 (doi: 10.1523/JNEUROSCI.0914-13.2013).

36. González C.R., González B. Exploring the stress impact in the paternal germ cells epigenome: can catecholamines induce epigenetic reprogramming? Frontiers in Endocrinol. (Lausanne), 2021, 11: 630948 (doi: 10.3389/fendo.2020.630948).

37. Chan J.C., Nugent B.M., Bale T.L. Parental advisory: maternal and paternal stress can impact offspring neurodevelopment. Biol. Psychiatry, 2018, 83(10): 886-894 (doi: 10.1016/j.biopsych.2017.10.005).

38. Rodriguez-Martinez H., Barth A.D. In vitro evaluation of sperm quality related to in vivo function and fertility. In: Reproduction in domestic ruminants VI. J.I. Juengel, J.F. Murray, M.F. Smith (eds.). Nottingham University Press, Nottingham, UK, 2007: 39-54 (doi: 10.12681/jhvms. 15588).

39. Lalancette C., Thibault C., Bachand I., Caron N., Bissonnette N. Transcriptome analysis of bull semen with extreme nonreturn rate: use of suppression-substractive hybridization to identify functional markers for fertility. Biol. Reprod., 2008, 78: 618-635 (doi: 10.1095/biolreprod.106.059030).

40. Miller D., Ostermeier G.C. Spermatozoal RNA: why is it there and what does it do? Gynecol. Obstet. Fertil., 2006, 34: 840-846 (doi: 10.1016/j.gyobfe.2006.07.013).

41. Tyuzikov I.A. Andrologiya i genital'naya khirurgiya, 2013, 2: 5-10 (in Russ.).

42. Bokarev I.N. Klinicheskaya meditsina, 2014, 8: 71-76 (in Russ.).

43. Abilov A.I., Amerkhanov Kh.A., Eskin G.V., Zhavoronkova N.V., Kombarova N.A., Fedorova E.V., Gusev I.V., Pyzhova E.A. Molochnoe i myasnoe skotovodstvo, 2015, 1: 29-33 (in Russ.).

44. Abilov A.I., Eskin G.V., Amerkhanov Kh.A., Kombarova N.A., Turbina I.S., Fedorova E.V., Gusev I.V., Zhavoronkova N.V. High sperm production as related to macro- and microelement levels in blood serum in servicing bulls of the modern selection. Sel'skokhozyaistvennaya biologiya [Agricultural Biology], 2014, 6: 96-106 (doi: 10.15389/agrobiology.2014.6.96eng).

45. Winter A.G., Zhao F., Lee R.K. Androgen deficiency and metabolic syndrome in men. Transl. Androl. Urol., 2014, 3(1): 50-58 (doi: 10.3978/j.issn.2223-4683.2014.01.04).

46. Pivonello R., Menafra D., Riccio E., Garifalos F., Mazzella M., de Angelis C., Colao A. Metabolic disorders and male hypogonadotropic hypogonadism. Frontiers in Endocrinology, 2019, 10: 345 (doi: 10.3389/fendo.2019.00345).

47. Abilov A.I., Mityashova O.S., Mymrin S.V., Gudilina A.A., Pyzhova E.A., Kombarova N.A., Levina G.N. Endogenous hormone level in bull sires in relation to age, autoimmune status, and production performance of maternal ancestors. Sel'skokhozyaistvennaya biologiya [Agricultural Biology], 2018, 53(4): 743-752 (doi: 10.15389/agrobiology.2018.4.743eng).

48. Abilov A.I., Mymrin S.V., Gudilina A.A., Mityashova O.S. Voprosy normativno-pravovogo regulirovaniya $v$ veterinarii, 2020, 1: 283-287 (doi: 10.17238/issn2072-6023.2020.1.283) (in Russ.).

49. Abilov A.I., Eskin G.V., Kombarova N.A. Blood estradiol level in bull sires influences sperm count and effectiveness of artificial insemination. Sel'skokhozyaistvennaya biologiya [Agricultural Biology], 2016, 51(6): 830-836 (doi: 10.15389/agrobiology.2016.6.830eng).

50. Amerkhanov Kh.A., Abilov A.I., Eskin G.V., Kombarova N.A., Turbina I.S., Fedorova E.V., Varennikov M.V., Gusev I.V. Concentration of testosterone and cholesterol in blood serum of 
servicing bulls depending on their type of productivity, age and the season. Sel'skokhozyaistvennaya biologiya [Agricultural Biology], 2014, 2: 59-66 (doi: 10.15389/agrobiology.2014.2.59eng) (in Russ.).

51. Kim T.W., Jeong J.H., Hong S.C. The impact of sleep and circadian disturbance on hormones and metabolism. Int. J Endocrinol., 2015, 2015: 591729 (doi: 10.1155/2015/591729).

52. Kumar Jha.P., Challet E., Kalsbeek A. Circadian rhythms in glucose and lipid metabolism in nocturnal and diurnal mammals. Mol. Cell Endocrinol., 2015, 418(Pt 1): 74-88 (doi: 10.1016/j.mce.2015.01.024).

53. Ouyang J.Q., Davies S., Dominoni D. Hormonally mediated effects of artificial light at night on behavior and fitness: linking endocrine mechanisms with function. J. Exp. Biol., 2018, 221(Pt 6): jeb156893 (doi: 10.1242/jeb.156893).

54. Bedrosian T.A., Fonken L.K., Nelson R.J. Endocrine effects of circadian disruption. Annu. Rev. Physiol., 2016, 78: 109-131 (doi: 10.1146/annurev-physiol-021115-105102).

55. Russart K.L.G., Nelson R.J. Light at night as an environmental endocrine disruptor. Physiol. Behav., 2018, 190: 82-89 (doi: 10.1016/j.physbeh.2017.08.029).

56. Hut R.A., Paolucci S., Dor R., Kyriacou C.P., Daan S. Latitudinal clines: an evolutionary view on biological rhythms. Proc. Biol. Sci., 2013, 280(1765): 20130433 (doi: 10.1098/rspb.2013.0433).

57. Poletaeva A.B., Alenikova A.E., Krivonogova O.V. Vestnik Ural'skoi meditsinskoi akademicheskoi nauki, 2009, 2/1(24): 290-292 (in Russ.).

58. Solonin Yu.G. Zhurnal mediko-biologicheskikh issledovanii, 2019, 7(2): 228-239 (doi: 10.17238/issn2542-1298.2019.7.2.228) (in Russ.).

59. Wacker M., Holick M.F. Sunlight and Vitamin D: A global perspective for health. Dermatoendocrinol., 2013, 5(1): 51-108 (doi: 10.4161/derm.24494).

60. Aziz M., Yadav K.S. Vitamin D deficiency in metabolic syndrome patients. International Journal of Advanced Research, 2016, 4(7): 229-241 (doi: 10.21474/IJAR01/894).

61. Holick M.F. Vitamin D deficiency. N. Engl. J. Med., 2007, 357(3): 266-281 (doi: 10.1056/NEJMra070553).

62. Hasnulin V. Geophysical perturbations as the main cause of Northern stress. Alaska Medicine, 2007, 49(2 Suppl): 237-244.

63. Krymova T.G., Kolkutin V.V., Dobrovol'skaya M.V. Problemy ekspertizy v meditsine, 2007, 26(2): 39-40 (in Russ.).

64. Natsional'naya tekhnologiya zamorazhivaniya i ispol'zovaniya spermy plemennykh bykov proizvoditelei [National technology of freezing and using semen of pedigree bull sires]. Moscow, 2008 (in Russ.).

65. Kurganova I.N. Lopes de Gerenyu V.O., Ableeva V.A., Bykhovets S.S. Fundamental'naya i prikladnaya klimatologiya, 2017, 4: 66-82 (doi: 10.21513/2410-8758-2017-4-66-82) (in Russ.).

66. Shklyaev V.A., Shklyaeva L.S. Vestnik Chelyabinskogo Gosudarstvennogo Universiteta, 2011, 5: 6169 (in Russ.).

67. SHurr A.V. Pskovskii regionologicheskii zhurnal, 2014, 20: 46-55 (in Russ.).

68. Rogovskaya N.V., Filippov R.V. Vestnik evraziiskoi nauki, 2014, 3(22): 64 (in Russ.).

69. Dan'shin A.I. Vestnik Rossiiskogo universiteta druzhby narodov. Seriya: Ekonomika, 2017, 25(4): 543-552 (doi: 10.22363/2313-2329-2017-25-4-543-552) (in Russ.).

70. Gusev I.V., Rykov R.A. Molochno-myasnoe skotovodstvo, 2018, 6: 22-25 (in Russ.).

71. Alabada H.K.M., Saleh W.M.M. Vitamin D effectiveness and pathology in humans and domestic animals. Multidisciplinary Reviews, 2020, 3: 1-15 (doi: 10.29327/multi.2020010).

72. Shil'nikov I.A., Akanova N.I., Temnikov V.N. Agrokhimicheskii vestnik, 2008, 6: 28-31 (in Russ.).

73. Mitrofanova E.M. Agrarnyi vestnik Urala, 2011, 2(81): 9-11 (in Russ.).

74. Pashkov S.V., Baibusinova S.B. Vestnik ZabGU, 2017, 2: 16-27 (in Russ.).

75. Kovalev I.V., Sarycheva I.V. Vestn. Mosk. un-ta. Ser. 17, Pochvovedenie, 2007, 2: 30-36 (in Russ.).

76. Ivanishchev V.V. Izvestiya Tul'skogo gosudarstvennogo universiteta. Estestvennye nauki, 2019, 3: 127-138 (in Russ.).

77. Shinoda S., Yoshizawa S., Nozaki E., Tadai K., Arita A. Marginally excessive iron loading transiently blocks mucosal iron uptake in iron-deficient rats. American Journal of Physiology-Gastrointestinal and Liver Physiology, 2014, 307(1): G89-G97 (doi: 10.1152/ajpgi.00305.2013).

78. Polyakova V.V. Izvestiya Vysshikh uchebnykh zavedenii. Lesnoi zhurnal, 2015, 3(345): $29-34$ (in Russ.).

79. Geary T.W., Waterman R.C., Van Emon M.L., Ratzburg C.R., Lake S., Eik B.A., Armstrong D.R., Zezeski A.L., Heldt J.S. Effect of supplemental trace minerals on novel measures of bull fertility. Transl. Anim. Sci., 2019, 3(Suppl 1): 1813-1817 (doi: 10.1093/tas/txz102).

80. Pal R., Mani V., Mir S., Singh R., Sharma R. Importance of trace minerals in the ration of breeding bull - a review. International Journal of Current Microbiology and Applied Sciences, 2017, 6(110: 218-224 (doi: 10.20546/ijcmas.2017.611.026).

81. Pipan M.Z., Mrkun J., Strajn B.J., Vrta K.P., Kos J., Pišlar A., Zrimšek P. The influence of macro- and microelements in seminal plasma on diluted boar sperm quality. Acta Vet. Scand., 2017, 59(1): 11 (doi: 10.1186/s13028-017-0279-y). 
82. Kerns K., Zigo M., Sutovsky P. Zinc: a necessary ion for mammalian sperm fertilization competency. Int. J. Mol. Sci., 2018, 19(12): 4097 (doi: 10.3390/ijms19124097).

83. Semenova L.I., Ponomareva S.M. Nauchnoe obozrenie. Fundamental'nye i prikladnye issledovaniya, 2018, 5: 8 (in Russ.).

84. Golubkina N.A., Sindireva A.V., Zaitsev V.F. Yug Rossii: ekologiya, razvitie, 2017, 1: 107-127 (doi: 10.18470/1992-1098-2017-1-107-127) (in Russ.).

85. Ermakov V.V. Biogeochemical regioning problems and the biogeochemical selenium provinces in the former USSR. Biol. Trace Element Res., 1992, 33(3): 171-185.

86. Yatoo M.I., Saxena A., Deepa P.M., Habeab B.P., Devi S., Jatav R.S., Dimri U. Role of trace elements in animals: a review. Veterinary World, 2013, 6(12): 963-967 (doi: 10.14202/vetworld.2013.963-967).

87. Malinin M.L., Kuznetsova A.E., Shibaeva M.A., Karablin P.M., Tikhomirova E.I., Laskavyi V.N. Fundamental'nye issledovaniya, 2013, 10(8): 1758-1761 (in Russ.).

88. Robles-Diaz M., Garcia-Cortes M., Medina-Caliz I., Gonzalez-Jimenez A., GonzalezGrande R., Navarro J.M., Castiella A., Zapata E.M., Romero-Gomez M., Blanco S., Soriano G., Hidalgo R., Ortega-Torres M., Clavijo E., Bermudez-Ruiz P.M., Lucena M.I., Andrade R.J., Spanish DILI Registry, Faster Evidence-based Translation (SAFE-T) Consortium. The value of serum aspartate aminotransferase and gamma-glutamyl transpetidase as biomarkers in hepatotoxicity. Liver Int., 2015, 35(11): 2474-2482 (doi: 10.1111/liv.12834).

89. Zou Y., Zhong L., Hu C., Sheng G. Association between the alanine aminotransferase/aspartate aminotransferase ratio and new-onset non-alcoholic fatty liver disease in a no obese Chinese population: a population-based longitudinal study. Lipids Health Dis., 2020, 19: 245 (doi: 10.1186/s12944-020-01419-z).

90. Reshetnikova N.M., Eskin G.V., Kombarova H.A., Poroshina E.S., Shavyrin I.I. Problemy biologii produktivnykh zhivotnykh, 2011, 54: 116-121 (in Russ.).

91. Ndrepepa G. Aspartate aminotransferase and cardiovascular disease - a narrative review. J. Lab. Precis. Med., 2021, 6: 6 (doi: 10.21037/jlpm-20-93).

92. Shamban L., Patel B., Williams M. Significantly elevated liver alkaline phosphatase in congestive heart failure. Gastroenterology Research, 2014, 7(2): 64-68 (doi: 10.14740/gr600w).

93. Cheung C.L., Cheung B.M.Y. Bone-specific alkaline phosphatase is elevated in insulin resistance: implications for vascular calcification in diabetes. European Heart Journal, 2013, 34(suppl_1): P5473 (doi: 10.1093/eurheartj/eht310.P5473).

94. Bogolyubova N.V., Rykov R.A. Molochnoe i myasnoe skotovodstvo, 2020, 3: $46-49$ (in Russ.).

95. Shkuratova I.A., Belousov A.I., Khalturina L.V., Busygina O.A. Veterinariya, 2020, 5: 48-52 (doi: 10.30896/0042-4846.2020.23.5.48-53) (in Russ.).

96. Milovanov V.K. Biologiya vosproizvedeniya i iskusstvennoe osemenenie zhivotnykh [Reproduction biology and artificial insemination of animals]. Moscow, 1962 (in Russ.).

97. White I.G. Lipids and calcium uptake of sperm in relation to cold shock and preservation: a review. Reprod. Fertil. Dev., 1993, 5(6): 639-658 (doi: 10.1071/rd9930639).

98. Chung T.H., Kwon Y.J., Lee Y.J. High triglyceride to HDL cholesterol ratio is associated with low testosterone and sex hormone-binding globulin levels in middle-aged and elderly men. Aging Male, 2020, 23(2): 93-97 (doi: 10.1080/13685538.2018.1501015).

99. Masaki H., Kim N., Nakamura H., Kumasawa K., Kamata E., Hirano K.I., Kimura T.. Long-chain fatty acid triglyceride (TG) metabolism disorder impairs male fertility: a study using adipose triglyceride lipase deficient mice. Mol. Hum. Reprod., 2017, 23(7): 452-460 (doi: 10.1093/molehr/gax031).

100. Laursen A.H., Bjerrum O.W., Friis - Hansen L., Hansen T.O., Marott J.L., Magnussen K. Causes of iron overload in blood donors - a clinical study. Vox Sanguinis, 2018, 113(2): 110-119 (doi: 10.1111/vox.12619).

101. Polunina T.E., Maev I.V. Meditsinskii sovet, 2008, 9-10: 41-52 (in Russ.).

102. Babichev V.N. Problemy endokrinologii, 2013, 59(1): 62-69 (doi: 10.14341/probl201359162-69) (in Russ.).

103. Vanita P., Jhansi K. Metabolic syndrome in endocrine system. J. Diabetes Metab., 2011, 2: 163 (doi: 10.4172/2155-6156.1000163).

104. Blakemore J., Naftolin F. Aromatase: contributions to physiology and disease in women and men. Physiology, 2016, 31: 258-269 (doi: 10.1152/physiol.00054.2015).

105. Grossmann M. Low testosterone in men with type 2 diabetes: significance and treatment. J. Clin. Endocrinol. Metab., 2011, 96(8): 2341-2353 (doi: 10.1210/jc.2011-0118).

106. Bekaert M., Van Nieuwenhove Y., Calders P., Cuvelier C.A., Batens A.H., Kaufman J.M., Ouwens D.M., Ruige J.B. Determinants of testosterone levels in human male obesity. Endocrine, 2015, 50(1): 202-211 (doi: 10.1007/s12020-015-0563-4).

107. Santi D., Spaggiari G., Granata A.R.M., Setti M., Tagliavini S., Trenti T., Simoni M. Seasonal changes of serum gonadotropins and testosterone in men revealed by a large data set of real-world observations over nine years. Frontiers in Endocrinology (Lausanne), 2020, 10: 914 (doi: 
10.3389/fendo.2019.00914).

108. Tracz M.J., Sideras K., Boloca E.R., Haddad R.M., Kennedy C.C., Uraga M.V., Caples S.M., Erwin P.J., Montori V.M. Testosterone use in men and its effects on bone health. A systematic review and meta-analysis of randomized placebo-controlled trials. J. Clin. Endocrinol. Metab., 2006, 91(6): 2011-2016 (doi: 10.1210/jc.2006-0036).

109. Kim T.W., Jeong J.H., Hong S.C. The impact of sleep and circadian disturbance on hormones and metabolism. International Journal of Endocrinology, 2015, 2015: 591729 (doi: 10.1155/2015/591729).

110. Gubina A.E., Koinosov A.P. Ekologiya cheloveka, 2018, 2: 31-36 (doi: 10.33396/1728-0869-20182-31-36) (in Russ.).

111. Hut R.A., Paolucci S., Dor R., Kyriacou C.P., Daan S. Latitudinal clines: an evolutionary view on biological rhythms. Proc. R. Soc. B, 2013, 280(1765): 20130433 (doi: 10.1098/rspb.2013.0433).

112. Kuznetsova E.A., Adamchik A.S. Sovremennye problemy nauki i obrazovaniya, 2016, 3: 122 (in Russ.).

113. Thun R., Eggenberger E., Zerobin K., Lüscher T., Vetter W. Twenty-four-hour secretory pattern of cortisol in the bull: evidence of episodic secretion and circadian rhythm. Endocrinology, 1981, 109(6): 2208-2212 (doi: 10.1210/endo-109-6-2208).

114. Patyukov A.G., Stepanova I.P., Makarova YA.S., Mugak V.V. Zootekhniya, 2014, 4: 28-29 (in Russ.).

115. Yuan G., Al-Shali K.Z., Hegele R.A. Hypertriglyceridemia: its etiology, effects and treatment. Canadian Medical Association Journal, 2007, 176(8): 1113-1120 (doi: 10.1503/cmaj.060963).

116. Kuznetsova E.A., Adamchik A.S., Goncharov N.P., Katsiya G.V. Andrologiya i genital'naya khirurgiya, 2016, 17(1): 26-31 (doi: 10.17650/2070-9781-2016-17-1-28-33) (in Russ.).

117. Maduka I.C., Neboh E.E., Ufelle S.A. The relationship between serum cortisol, adrenaline, blood glucose and lipid profile of undergraduate students under examination stress. African Health Sciences, 2015, 15(1): 131-136 (doi: 10.4314/ahs.v15i1.18).

118. Platonova N.M. Klinicheskaya $i$ eksperimental'naya tireoidologiya, 2015, 11(1): 12-21 (doi: 10.14341/ket2015112-21) (in Russ.).

119. Björndahl L., Kvist U. Human sperm chromatin stabilization: a proposed model including zinc bridges. Mol. Hum. Reprod., 2010, 16(1): 23-29 (doi: 10.1093/molehr/gap099).

120. Prasad A.S. Zinc in human health. In: Personalized medicine, in relation to redox state, diet and lifestyle. Ch. 10 /F. Atroshi (ed.). IntechOpen, 2020 (doi: 10.5772/intechopen.92005).

121. Beigi Harchegani A., Dahan H., Tahmasbpour E., Bakhtiari Kaboutaraki H., Shahriary A. Effects of zinc deficiency on impaired spermatogenesis and male infertility: the role of oxidative stress, inflammation and apoptosis. Hum. Fertil. (Camb.), 2020, 23(1): 5-16 (doi: 10.1080/14647273.2018.1494390).

122. Bozhedomov V.A, Gromenko D.S., Ushakova I.V., Toroptseva M.V., Galimov SH.N., Golubeva E.L., Okhtyrskaya T.A., Aleksandrova L.A., Sukhikh G.T. Problemy reproduktsii, 2008, 6: 67-73 (in Russ.).

123. Kasperczyk A., Dobrakowski M., Czuba Z.P., Kapka-Skrzypczak L., Kasperczyk S. Influence of iron on sperm motility and selected oxidative stress parameters in fertile males - a pilot study. Ann. Agric. Environ. Med., 2016, 23(2): 292-296 (doi: 10.5604/12321966.1203893).

124. Amstislavskaya T.G., Popova N.K. Obzory po klinicheskoi farmakologii i lekarstvennoi terapii, 2009, 7(2): 3-2 (in Russ.).

125. Lephart E.D., Call S.B., Rhees R.W., Jacobson N.A., Weber K.S., Bledsoe J., Teuscher C. Neuroendocrine regulation of sexually dimorphic brain structure and associated sexual behavior in male rats is genetically controlled. Biol. Reprod., 2001, 64(2): 571-578 (doi: 10.1095/biolreprod64.2.571).

126. Hitit M., Ugur M.R., Dinh T.T.N., Sajeev D., Kaya A., Topper E., Tan W., Memili E. Cellular and functional physiopathology of bull sperm with altered sperm freezability. Frontiers in Veterinary Science, 2020, 7: 581137 (doi: 10.3389/fvets.2020.581137).

127. Trubnikov D.V. Vestnik Kurskoi gosudarstvennoi sel'skokhozyaistvennoi akademii, 2015, 1: 69-71 (in Russ.).

128. Hassan M.H., El-Taieb M.A., Fares N.N., Fayed H.M., Toghan R., Ibrahim H.M. Men with idiopathic oligoasthenoteratozoospermia exhibit lower serum and seminal plasma melatonin levels: Comparative effect of night-light exposure with fertile males. Experimental and Therapeutic Medicine, 2020, 20(1): 235-242 (doi: 10.3892/etm.2020.8678).

129. Awad H., Halawa F., Mostafa T., Atta H. Melatonin hormone profile in infertile males. Int. J. Androl., 2006, 29: 409-413 (doi: 10.1111/j.1365-2605.2005.00624.x).

130. Diatroptov M.E., Simonova E.Yu., Diatroptova M.A. Rossiiskii mediko-biologicheskii vestnik imeni akademika I.P. Pavlova, 2013, 3: 107-113 (doi: 10.17816/PAVLOVJ20133107-113) (in Russ.).

131. Fatima N., Rana S. Metabolic implications of circadian disruption. Pflugers Arch. - Eur. J. Physiol., 2020, 472: 513-526 (doi: 10.1007/s00424-020-02381-6).

132. Amstislavskaya T.G. Psikhofarmakologiya i biologicheskaya narkologiya, 2008, 8(1-2/1): 2271-2279 (in Russ.). 
133. Hasnulin V.I., Voytik I.M., Hasnulina A.V., Ryabichenko T.I., Skosyreva G.A. Some ethnic features of northern aborigines' psychophysiology as a base for survival in extreme natural conditions: a review. Open Journal of Medical Psychology, 2014, 3(4): 292-300 (doi: 10.4236/ojmp.2014.34030).

134. Hassi J., Sikkilä K., Ruokonen A., Leppдluoto J. The pituitary-thyroid axis in healthy men living under subarctic climatological conditions. Journal of Endocrinology, 2001, 169(1): 195-203 (doi: 10.1677/joe.0.1690195). 